\title{
Safety risk assessment of heritage buildings in metro construction based on SPA theory: a case study in Zhengzhou, China
}

\author{
Qian Wang ${ }^{1}$, Changming Yang ${ }^{1 *} \mathbb{C}$, Lin Tian ${ }^{2^{*}}$, Jiguang $\mathrm{Lu}^{3}$, Fengwen $\mathrm{Wu}^{4}$ and Jianyong $\mathrm{An}^{3}$
}

\begin{abstract}
While the urban rail transit systems have been developed rapidly, the nearby heritage buildings and historic sites are facing possible threats of unexpected damages. In particular, a rail project has a potential impact on numerous heritage buildings and sites in an old city. Thus, to better protect these heritage buildings and sites, it is crucial for decision-makers to be able to rapidly and accurately evaluate these threats. Based on Set Pair Analysis (SPA) theory, this study developed a risk assessment model to assess the safety of heritage buildings adjacent to metro construction. In this model, the risk levels of adjacent heritage buildings are ranked. Moreover, this study establishes an assessment index system comprising 16 individual indexes among four categories related to heritage building, metro, soil, and management. The index system determines the interval values for each evaluation factor. To improve the reliability of the index weight, a linear weighting method was adopted. In this study, both subjective weights calculated via the Analytic Hierarchy Process (AHP) and objective weights calculated by the Clustering Weight Method (CWM) are analyzed comprehensively. Moreover, a case study was conducted by applying the proposed assessment model into assessing the structural safety risk of a heritage building adjacent to the Zhengzhou Metro Line Three. It was found the results of the proposed model were consistent with the Matter-Element (ME) method. The proposed model can be used to provide decision-making support for controlling risk on similar projects.
\end{abstract}

Keywords: Set pair analysis theory, Risk assessment, Heritage buildings, Shield tunneling, Risk control

\section{Introduction}

Recently, large underground rail transit systems are built in several Chinese cities to solve the issue of heavy traffic congestion [1, 2]. However, this underground rail development can have a huge impact on the surrounding urban environment [3]. For example, a shield tunneling can loose the surrounding soils above its roof and produce soil loss. Moreover, it can also cause nearby ground settlement, road surface cracking, excessive building deformation, and so on [4]. It is

\footnotetext{
*Correspondence: yangchangming@bjut.edu.cn; 994570277@qq.com ${ }^{1}$ Beijing Historical Building Protection Engineering Technology Research Center, Beijing University of Technology, Beijing 100124, China ${ }^{2}$ Institute of Architecture and Public Art, Chinese National Academy of Arts, Beijing 100029, China

Full list of author information is available at the end of the article
}

known that heritage buildings have incredible historic, artistic, and scientific value; however, the development of metro constructions has put potential damage onto the heritage buildings [5]. On September 23, 2009, in Tianjin, China, Metro Line Three was seriously flooded during construction, and this caused many cracks from the foundation up to the roof of the adjacent historic DD Hotel. The greatest crack was $70 \mathrm{~cm}$ wide, and the crack caused a partial collapse on the northwest side of the hotel [6]. Thus, the threats of potential damage to the safety of adjacent heritage buildings caused by metro construction should be investigated.

The damages to the structural integrity of adjacent heritage buildings caused by underground rail transit constructions happened not only in China, but across the world [7]. For example, on March 3, 2009, many cracks
Springer Open

(c) The Author(s) 2020. This article is licensed under a Creative Commons Attribution 4.0 International License, which permits use, sharing, adaptation, distribution and reproduction in any medium or format, as long as you give appropriate credit to the original author(s) and the source, provide a link to the Creative Commons licence, and indicate if changes were made. The images or other third party material in this article are included in the article's Creative Commons licence, unless indicated otherwise in a credit line to the material. If material is not included in the article's Creative Commons licence and your intended use is not permitted by statutory regulation or exceeds the permitted use, you will need to obtain permission directly from the copyright holder. To view a copy of this licence, visit http://creativeco mmons.org/licenses/by/4.0/. The Creative Commons Public Domain Dedication waiver (http://creativecommons.org/publicdomain/ zero/1.0/) applies to the data made available in this article, unless otherwise stated in a credit line to the data. 
were found on the external wall of the Historical Archives in Cologne (Germany) due to metro construction. The cracks quickly spread to the roof and triggered the collapse of the building [8]. The number of underground rail transit projects have largely increased in big cities. However, the above examples showed that they had caused many damages to heritage buildings. Thus, it is important for decision-makers to be able to evaluate the risks of shield construction on the safety of adjacent heritage buildings [9].

At present, research on the influence of underground rail transit construction on adjacent buildings has achieved significant outcomes in China and around the world. It was found that the main risk factor on a building is the induced surface settlements due to metro tunnel construction [10]. Research analysis methods for studying ground settlement or building damage caused by metro construction can be divided into three categories: Empirical Analysis (EA) [11], Finite Element Analysis (FEA) [12], and Mathematical Theoretical Analysis (MTA) (such as Bayesian Networks(BNs) [13], Information Fusion (IF) [14], and Extended Cloud Model (ECM) [15]).

Empirical analysis (EA) is an empirical method adopted at the early stage of research to obtain the common prior experience through statistical analysis of a large number of actual engineering monitoring data. It provides a theoretical guidance for engineering [16]. Peck developed the classic formula of surface settlement and used normal distribution to present the surface settlement trough [17]. Many other scholars such as Attewell et al. [18] and Rankin [19] further improved and revised the Peck's formula. Further, Bilotta et al. verified the Gaussian empirical curve and obtained the value range of empirical parameters by monitoring the surface settlement and deep displacement during the tunnel excavation along the metro lines 1 and 6 in Naples, Italy [9]. Sirivachiraporn et al. also analyzed a large number of monitoring data in the construction of the first subway project in Bangkok. They evaluated the complex surface settlement trend and the response of different pile buildings. Based on the analysis, they concluded that the surface settlement slot did not conform to the Gaussian function [11]. However, although EA has been widely used for its simplicity, it cannot accurately predict surface settlement, as there are unknown human factors and complex geological structures in metro construction. Thus, it can only be used to roughly estimate the surface settlement.

Finite Element Analysis (FEA) is a numerical simulation method developed by using the application of electronic computers [16]. It is a multi-parameter and dynamic analysis method, which has been widely used in the study of the impact of roadway on the surrounding environment to obtain a great number of empirical results. Camos et al. [12] proposed a new formula to calculate the horizontal strain of the tunnel, and developed a three-dimensional finite element model for building response to predict the damage of adjacent buildings. Li et al. [20] established the finite element numerical simulation model, discussed the ground settlement deformation law caused by tunnel construction under different soil constitutive models, and obtained the sensitivity of different soil parameters. FEA can be used to repeatedly simulate the real physical situation with high precision and visualization. However, it is a complicated modeling process, and requires a high level of relevant professional background and understanding of relevant theories. In addition, it is very time-consuming. Thus, when a metro line is built in the old part of a city, and there are many heritage buildings near the line that require an assessment of the impact of metro construction on structural safety, this method is deemed to be time-consuming and expensive.

Mathematical Theoretical Analysis (MTA) is a mathematical method developed based on the prior experience obtained by EA or FEA. It is mainly used to perceive the magnitude of risk for decision. For example, $\mathrm{Wu}$ and Zhang et al. studied a variety of mathematical methods and applied them into predicting building safety risks from tunnel constructions [4, 13-15]. Bayesian Networks (BNs), one MTA method, is developed based on probabilistic reasoning. It can solve the problems of uncertainty and incompleteness, but it is very complicated and has high computational demands. In addition, its analytical quality heavily relies upon large amount of reliable prior data samples. Information Fusion (IF), another MTA method, is developed based on the Dempster-Shafer evidence theory. It can fuse a variety of data, and is more intuitive than BNs. However, owing to its lack of solid theoretical underpinning for its synthesis rules, its rationality and effectiveness are limited. Another MTA method, Extended Cloud Model (ECM) can be used to evaluate the impact of metro tunnel shield construction in a simple, efficient, and convenient way, but it is easy to miss important information during its calculation process.

In summary, the above research methods are more focused on the impact on the building or a single building by metro constructions. However, limited research has been focusing on the heritage buildings themselves. For example, Bilotta et al. [21] conducted numerical analysis on a historic church building next to the Metro Line 6 tunnel which was under construction in downtown Naples. The analysis was undertaken through the establishment of three-dimensional finite element model to monitor the settlement on the surface and deep layer 
of the building. It was found the measured results were consistent with the hypothesized results. Other scholars also investigated the assessment of the impact of metro construction on a large number of cultural relics in the historic urban areas. For example, Chang established a chromatography multiply assessment method (CMAM) [6]. In CMAM, images were overlaid according to a chromatic principle through Photoshop or ArcGIS technology platform. The process was simple and the developed method produced intuitive, vivid, and concise images. However, the interactions between the metro tunnel and heritage building factors, as well as the contribution of soil factor and management factor, are not considered. In addition, it was only applicable to the evaluation of metro lines during the planning stage.

Although the detailed numerical analysis cannot be replaced to calculate the specific damage of the metro line to the high-risk heritage buildings [22], a simple, rapid and reliable in risk assessment on the safety of heritage buildings shall be developed to avoid unnecessary complicated numerical simulations spent on the lower risk buildings. It is also of practical significance to develop a thorough construction plan to ensure the structural safety of heritage buildings using shield tunneling during metro construction. Thus, this study is to develop a more convenient and efficient method to evaluate heritage buildings under the impact of nearby metro tunnel shield construction. The safety assessment method developed was using evaluation index factors related to heritage buildings, metro construction, soil conditions, and construction management. In addition, this method is developed by using mathematical tools based upon set pair analysis (SPA). The method is to rapidly assess the risk levels of adjacent heritage buildings impacted by the metro shield tunneling construction. By updating the data for each evaluation parameter, this study is to control potential risks in real time when shielding tunneling is used during metro constructions, and provide feedback for the adjustment and optimization of the construction plan.

\section{Methods}

\section{The SPA theory}

The SPA theory was first developed by Zhao in 1989 as a new systems analysis method. It focuses on studying the certainty and uncertainty of a given system [23]. In the given system, "identity", "opposition", and "difference" are commonly used terminologies. Identity and opposition represent two aspects of certainty, whereas the difference represents uncertainty. Moreover, identity, opposition, and difference are interrelated. They influence and restrain each other, and they transform into each other under certain conditions [24]. Their correlation is shown in Eq. (1), in which the dialectical understanding of uncertainty is transformed into a mathematical operation.

$$
\mu(w)=\frac{S}{N}+\frac{F}{N} i+\frac{P}{N} j=a+b i+c j
$$

where, $N$ is the total number of features with the set pair $H=(A, B)$ (assumption sets $A, B)$. It describes identity, opposition, and difference. $S$ represents the common features; $P$ represents opposite features; $F$ represents features that are neither common nor contrary, and $N=S+F+P$. The ratios, $S / N, F / N$, and $P / N$ are the identity degree, difference degree, and conflict degree of sets $A$ and $B$ respectively. Suppose $a=S / N, b=F / N$, $\mathrm{c}=\mathrm{P} / \mathrm{N}$, and $a+b+c=1$. The coefficients of the difference degree and conflict degree are $i$ and $j$, with $i \in[-1,+1]$ and $j=-1$. When $i=1$, the uncertainty is converted into an identity degree; when $i=-1$, the uncertainty is converted into a conflict degree; and when $i \in(-1,+1)$, there is a mixed degree of identity and opposition.

This study used the SPA theory to study the safety risk assessment of heritage buildings to develop a set pair, which involves the index of the heritage buildings and the classification standard of the index. If the index is within a certain evaluation level, it is considered to be identity; If it is within the separated evaluation level, it is considered to be conflict; If it is within the adjacent evaluation level, it is considered as difference. The closer it is to the evaluation level, the closer $i$ is to 1 . Moreover, the closer it is to the separated evaluation level, the closer $i$ is to -1 .

\section{Index normalization}

A comprehensive evaluation of multiple indexes shows the impact of metro construction on the safety of adjacent heritage buildings. However, each index has different types and units. Thus, it may be difficult to generalize the findings. Therefore, it is important to normalize each index to make it satisfy the principles of comparison.

$$
\begin{aligned}
& c_{i 1}^{\prime}=c_{i}-\min \left(c_{i}\right) / \max \left(c_{i}\right)-\min \left(c_{i}\right) \\
& c_{i 2}^{\prime}=\max \left(c_{i}\right)-c_{i} / \max \left(c_{i}\right)-\min \left(c_{i}\right)
\end{aligned}
$$

where $c_{i 1}^{\prime}$ is a "the smaller the better" index (negative index); $c_{i 2}$ is a "the bigger the better" index (positive index); $\max \left(c_{i}\right)$ is the maximum value of the $i$ th index; and $\min \left(c_{i}\right)$ is the minimum value of the $i$ th index.

\section{Index weight}

Weights can be divided into two categories: Subjective weights and objective weights. The subjective weight reflects the willingness from the decision-maker; while 
the objective weight reflects the contribution of specific index data. In the present study, both the subjective and objective weights were obtained using the Analytic Hierarchy Process (AHP) and the Clustering Weight Method (CWM). Moreover, a linear weighting method was adopted to determine the weight of each factor, with a view to enhancing the reliability of the evaluation results.

\section{The AHP approach}

The AHP approach separates relevant factors into a target layer, criterion layer, index layer, and other layers. It is a multi-level weight analysis method, which integrates the subjective judgments with the objective data analysis. In this approach, both qualitative and quantitative analyses were conducted into a concise systematic analysis and evaluation method [25].

The AHP theory itself is very well developed, and it has been widely used by many researchers in different industries. The specific calculation formula and derivation processes are explained in the relevant literature $[26,27]$. However, it is worth noting that testing of the results' consistency should be conducted. When this testing is completed successfully, the eigenvector can be used as the weight vector. Otherwise, the judgment matrix needs to be reconstructed until the consistency test was completed successfully.

\section{The CWM approach}

In the CWM approach, the clustering weight is usually calculated via a simple threshold method. However, this method neglects the differences in the ranges of each index's standard value [28]. Therefore, this study uses a revised CWM approach, in which the weight of each index at the different levels is determined by using the measured value of the samples and the standard value of the evaluation index at each level. The specific steps are as follows:

Step 1: Construct the original decision matrix as follows.

$$
R=\left(x_{i j}\right)_{n m}(i=1,2, \ldots, n ; j=1,2, \ldots, m)
$$

where $x_{i j}$ is the upper threshold of the $i$ th index at the $j$ th level.

Step 2: Calculate the weight distribution of each index as follows.

$$
\begin{aligned}
& x_{i j}^{\prime}=x_{i j} / \sum_{j=1}^{m} x_{i j}(i=1,2, \ldots, n ; j=1,2, \ldots, m) \\
& y_{i j}^{\prime}=x_{i j}^{0} / x_{i j}^{\prime}(i=1,2, \ldots, n ; j=1,2, \ldots, m)
\end{aligned}
$$

where $y_{i j}^{\prime}$ is the weight distribution of each index, and $x_{i j}^{0}$ is the normalized evaluation value of the actual sample.

Step 3: Calculate the clustering weight.

$$
Z_{i}=\sum_{j=1}^{m} y_{i j}^{\prime} / \sum_{i=1}^{n} \sum_{j=1}^{m} y_{i j}^{\prime}
$$

where $Z_{i}$ is the clustering weight of the $i$ th index.

\section{Comprehensive weight}

The comprehensive weight can be calculated in Eq. (8).

$$
w_{i}^{\prime}=a \times w_{i}+(1-a) \times Z_{i}, a \in[0,1]
$$

where $w_{i}$ is the AHP weight; $Z_{i}$ is the CWM weight; and $a$ is a weight coefficient that varies in different projects.

\section{SPA correlation degree}

The SPA evaluation method calculates the correlation value, and the coefficient of the difference. Different from the Set Membership method, the SPA method has a wide-domain functional structure to improve the information utilization rate and ensure the credibility of the comprehensive results [29]. In Table 1, five correlationdegree functions are listed. $\mu_{i}(j)$ was constructed for the safety risk evaluation index for adjacent heritage buildings influenced by shield tunneling construction. The degree-of-correlation models of levels $\mathrm{I}-\mathrm{V}$ are shown in Eqs. (9)-(13).

$$
\begin{aligned}
& \mu_{i}(1)=\left\{\begin{array}{cc}
1 & x_{i} \in\left[0, s_{i(1)}\right] \\
1-\frac{2\left(x_{i}-s_{i(1)}\right)}{\left(s_{i(2)}-s_{i(1)}\right)} & x_{i} \in\left(s_{i(1)}, s_{i(2)}\right. \\
-1 & x_{i} \in\left(s_{i(2)}, s_{i(5)}\right.
\end{array}\right] \\
& \mu_{i}(2)=\left\{\begin{array}{cc}
1 & x_{i} \in\left(s_{i(1)}, s_{i(2)}\right] \\
-1+\frac{2 x_{i}}{s_{i(1)}} & x_{i} \in\left[0, s_{i(1)}\right] \\
1-\frac{2\left(s_{i}-s_{i(2)}\right)}{\left(s_{i(3)}-s_{i(2)}\right)} & x_{i} \in\left(s_{i(2)}, s_{i(3)}\right] \\
-1 & x_{i} \in\left(s_{i(3)}, s_{i(5)}\right]
\end{array}\right.
\end{aligned}
$$

$$
\mu_{i}(3)=\left\{\begin{array}{cc}
1 & x_{i} \in\left(s_{i(2)}, s_{i(3)}\right] \\
-1+\frac{2\left(x_{i}-s_{i(1)}\right)}{\left(s_{i(2)}-s_{i(1)}\right)} & x_{i} \in\left(s_{i(1)}, s_{i(2)}\right] \\
1-\frac{2\left(x_{i}-s_{i(3)}\right)}{\left(s_{i(4)}-s_{i(3)}\right)} & x_{i} \in\left(s_{i(3)}, s_{i(4)}\right] \\
-1 & x_{i} \in\left[0, s_{i(1)}\right] \cup\left(s_{i(4)}, s_{i(5)}\right]
\end{array}\right.
$$

$$
\mu_{i}(4)=\left\{\begin{array}{cc}
1 & x_{i} \in\left(s_{i(3)}, s_{i(4)}\right] \\
-1+\frac{2\left(x_{i}-s_{i(2)}\right)}{\left(s_{i(3)}-s_{i(2)}\right)} & x_{i} \in\left(s_{i(2)}, s_{i(3)}\right] \\
1-\frac{2\left(x_{i}-s_{i(4)}\right)}{\left(s_{i(5)}-s_{i(4)}\right)} & x_{i} \in\left(s_{i(4)}, s_{i(5)}\right] \\
-1 & x_{i} \in\left[0, s_{i(2)}\right]
\end{array}\right.
$$




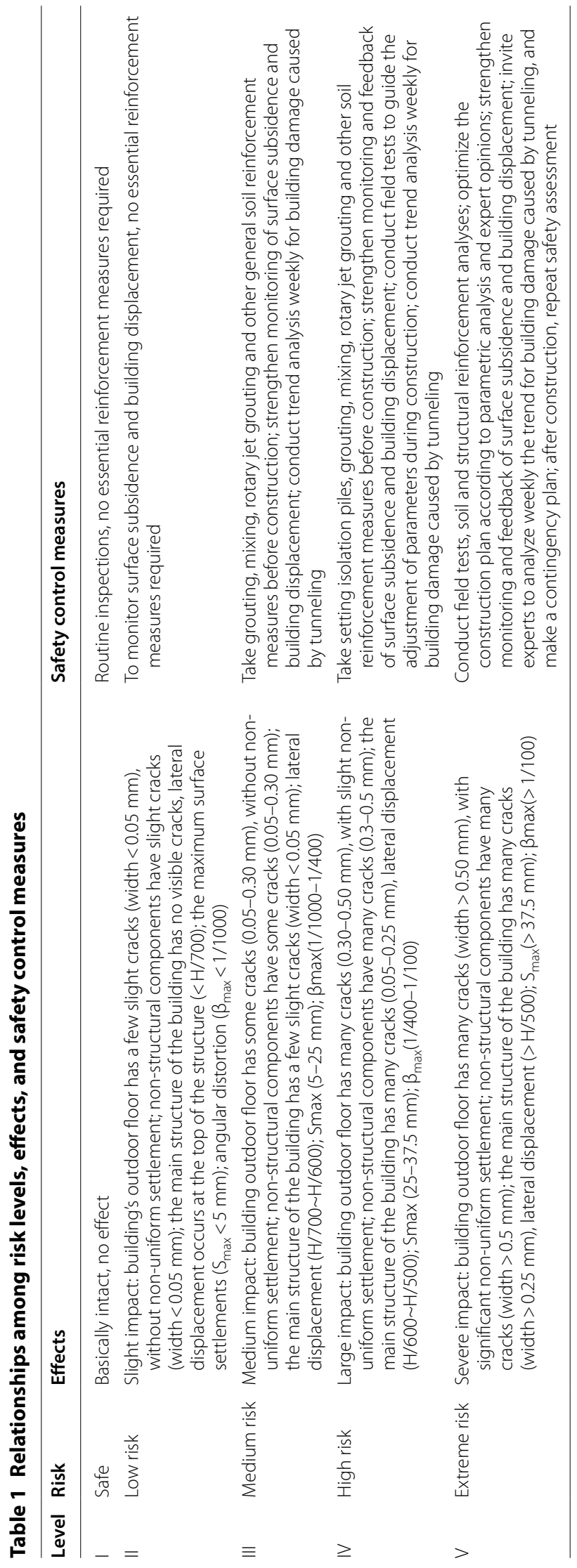




$$
\mu_{i}(5)=\left\{\begin{array}{cc}
1 & x_{i} \in\left(s_{i(4)}, s_{i(5)}\right. \\
-1+\frac{2\left(x_{i}-s_{i(3)}\right)}{\left(s_{i(4)}-s_{i(3)}\right)} & x_{i} \in\left(s_{i(3)}, s_{i(4)}\right. \\
-1 & x_{i} \in\left[0, s_{i(3)}\right.
\end{array}\right]
$$

In Eqs. (9)-(13), $\mu_{i}(1)$ to $\mu_{i}(5)$ are the degrees of correlation of each index $i$ for the five assessment levels, with $\mathrm{i}=1,2,3, \ldots, 16 ; s_{i(1)}$ to $s_{i(5)}$ are the upper thresholds for the respective levels $\mathrm{I}-\mathrm{V}$ in the normalized safety risk evaluation criteria, and $s_{i(1)} \neq s_{i(2)} \neq s_{i(3)} \neq s_{i(4)} \neq s_{i(5)}$. $x_{i}$ is the normalized measured value of the $i$ th index. By substituting the measured values of each index into the above models, the correlation degree of each evaluation level can be obtained.

Equation (14) is to calculate the average degree of correlation.

$$
\mu_{j}=\sum_{i=1}^{n} w_{i}^{\prime} \mu_{i}(j)
$$

where $\mu_{j}$ is the average correlation degree of the safety risk index on the jth evaluation level; and $w_{i}^{\prime}$ is the comprehensive weight of each safety risk index.

If $\mu_{k}=\max \left\{\mu_{j}\right\}, k=1,2, \ldots, m$, the safety risk assessment result of the sample can be identified at the $k$ th level.

\section{Safety risk assessment model Standard grades of risk}

According to the relevant standard specification [30] and previous literature [14, 15, 31], combined with safety control measures and protection requirements of heritage buildings, the structural safety of adjacent heritage buildings under the influence of metro construction can be classified into five levels. In details, the five levels are I (safe), II (low risk), III (medium risk), IV (high risk) and V (extreme risk). Table 1 shows the relationships among the risk levels, effects, and the safety control measures of heritage buildings.

\section{Selection of evaluation factors}

The main reason for the impact on the structural safety of adjacent heritage buildings is the loss of soil around the tunnel caused by metro shield construction, which leads to uneven settlement of the site in the area where the heritage buildings are located, thus threatening the structural safety of these buildings [32]. The impact factors that metro construction has on the structure of heritage buildings is divided into three main ones: building, soil, and metro tunnel. However, the construction management is indispensable. An effective safety management has to be implemented to control risks in a timely manner and ensure the safety of the construction site and surrounding environment [33]. Thus, the evaluation factors are derived from four sources: heritage building, metro construction, soil, and management.

(1) Heritage building factors $\left(b_{1}\right)$ : the importance degree $\left(c_{1}\right)$ of the heritage building consists of its protection level, historic value, scientific value and artistic value [34]. The higher the importance degree is, the greater the loss can be. Therefore, the high "important" heritage buildings have high safety risk levels. Moreover, heritage buildings may have structural deterioration owing to its age, and it can impact on their carrying capacity [14]. That is, when the deterioration degree $\left(c_{4}\right)$ is higher, the safety risk level of the buildings is higher. In addition, a heritage building's resistance to external environmental influence shall also be accounted. For example, Wu studied building size and the relationship between the deformation: geometric character $\left(c_{2}\right)$ [35]; Chinese code GB50292-2015 established the appraisal of the existing structure security: structure type $\left(c_{3}\right)$ [30].

(2) Metro construction factors $\left(b_{2}\right)$ : The distance between the metro construction and a nearby heritage building is an important factor affecting the safety of these buildings $[32,36]$. The distance includes the cover depth ( $c_{5}$ the vertical distance from the tunnel roof to the ground [37]) and the horizontal distance $\left(c_{6}\right)$. Peck found the land subsidence is caused by the loss of soil. And there is a positive correlation between the soil loss and the tunnel diameter $\left(c_{7}\right)$ [17]. In addition, the main parameters of shield tunneling during the shield construction such as the advancing speed $\left(c_{8}\right)$, the TBM pressure and the grouting have a significant impact on the surface settlements $[22,38]$. Both the TBM pressure and the grouting are specific values calculated by the numerical simulation or engineering practice experience [22]. The change of the values will increase the risk, as they do not follow a linear correlation. Therefore, they are not included for the assessment model.

(3) Soil factors $\left(b_{3}\right)$ : Soil is the interactive medium between the heritage building and the metro construction, and thus, it is a factor directly affecting the safety of heritage building [14]. Friction angle ( $\left.c_{9}\right)$, Compression modulus $\left(c_{10}\right)$, Poisson's ratio $\left(c_{11}\right)$, and cohesion are the main parameters of the engineering geological characteristics [39]. Li et al. conducted the sensitivity analysis of influencing factors of surface settlement during tunnel construction, and found Poisson's ratio > Friction angle $>$ Compression modulus $>$ cohesion [20]. Zhang et al. also conducted a study on the sensitivity of stratum parameter changes to surface settlement, and concluded that the sensitivity of cohesion was the lowest, which was 
approximately $1 / 20 \sim 1 / 10$ of Compression modulus or Friction angle [40]. Thus, the cohesion was not selected in the present study. Soil loss rate $\left(c_{12}\right)$ is the soil loss per unit in the soil excavation area. The larger the loss rate is, the greater the soil loss per unit area is. Moreover, the more significant the ground subsidence, and the greater the impact on the heritage buildings is [41].

(4) Management factors $\left(b_{4}\right)$ : Construction management is a dynamic process that involves people, materials, machinery, law, and the environment at the construction site [42]. High-frequency and high-precision monitoring measurement $\left(c_{13}\right)$, an efficient management system $\left(c_{14}\right)$, an ideal contingency plan $\left(c_{15}\right)$, and a professional monitoring engineer $\left(c_{16}\right)$ are the key factors to ensure construction safety.

The influence of metro construction using shield tunneling on heritage buildings can be assessed by developing an index system. Based upon the above review, the 16 indexes listed in Table 2 were selected to develop the safety risk evaluation index system of heritage buildings. The system has four categories: heritage building factors, metro construction factors, soil factors, and management factors.

\section{Grade division standard of evaluation factors}

The proposed safety risk evaluation index system for adjacent heritage buildings under the influence of metro construction using shield tunneling involves both objective evaluation factors (e.g. construction and soil) and subjective evaluation factors (e.g. building and management). Each factor has a certain contribution to the ultimate risk level. Therefore, it is important to analyze the intervals of the evaluation factors. Objective factors were measured by actual values on a project, while subjective factors are determined by relevant experts. Table 3 shows the scoring details of subjective factors based on a 100-mark system (0-100) [14]. The intervals for each factor are recognized by combining with engineering practices and theoretical analysis [15]. Table 4 shows the evaluation criteria for each index. Table 5 presents the normalized results of the values for each index in Table 4 according to Eqs. (2) and (3).

\section{Case study verification}

This case study involves a heritage building located at 27 Square in the old town of Zhengzhou in Henan Province. Built in 1971, the building is a cultural monument with hexagonal conjoined twin towers. Built by reinforced concrete, this 14-floor building is $63 \mathrm{~m}$ high. There are three floors underground in the base surrounded by white marble fence. The bottom tower has 11 floors, and another hexagonal bell tower $(2.7 \mathrm{~m}$ in diameter) stands on its top (see Fig. 1). It has a $1500-$ mm-thick raft foundation, under which lie $200 \mathrm{~mm}$ of plain concrete and $800 \mathrm{~mm}$ of thick sand cushion. This heritage building was declared by the State Council of the People's Republic of China as a National Key Cultural Relic Protection Unit in 2006.

The tunnel of the Zhengzhou Metro Line Three (ZMLT) runs alongside the heritage building. The horizontal distance between the tunnel edge and the building is only $3 \mathrm{~m}$, and the vertical distance between them is 20.5 m. Their spatial image is illustrated in Fig. 2.

Before the metro construction, a detailed geotechnical investigation must be conducted along the metro line. The soil layer traversed by ZMLT is mainly silty clay, with silty sand and fine sand in some parts. The engineering geological section is shown in Fig. 3.

\section{Data acquisition}

The values of objective indexes were obtained through the geotechnical investigation report and the metro construction drawing. The report includes the sections of the friction angle, compression modulus, the Poisson's ratio and other relevant information about their different horizontal distances. The metro construction drawing includes the cover depth and the tunnel diameter. The soil loss rate in clay was $1.0 \% \sim 1.5 \%$ [41]. It is easy for fine sand to produce formation loss, and thus soil loss rate will increase. Therefore, the soil loss rate was $1.05 \sim 1.31 \%$ according to the previous construction experience and geological conditions. The subjective indexes were obtained by using the scores given by domain experts on heritage building factors and management factors. Table 6 lists the values of each evaluation index. Table 7 shows the corresponding normalized evaluation indexes using Eqs. (2) and (3).

\section{Correlation calculation}

Taking the measured data set as an example. The nearest horizontal distance between the tunnel and the building was set as $3 \mathrm{~m}$, and the advancing speed for the shield machine was tentatively set at $40 \mathrm{~mm} / \mathrm{min}$. The following two sections demonstrates the calculation processes.

\section{Weights calculation}

Based on the established hierarchical structure model, Table 8 shows the 1-9 scale method was adopted to compare the judgment matrixes of the criterion layer 
Table 2 Safety risk evaluation index system of heritage buildings

\begin{tabular}{|c|c|c|c|}
\hline Target (0) & Criteria (B) & Index (C) & Description \\
\hline \multirow[t]{3}{*}{$\begin{array}{l}\text { Safety risk of } \\
\text { heritage } \\
\text { buildings }\end{array}$} & $\begin{array}{l}\text { Heritage building factors } \\
\qquad\left(b_{1}\right)\end{array}$ & Importance degree $c_{1}$ (score) & $\begin{array}{l}\text { Subjective index. Heritage buildings are of great value and are precious } \\
\text { material and spiritual wealth left by ancestors [34]. The more } \\
\text { important they are, the greater the loss after the disaster, and the } \\
\text { higher the risk level }\end{array}$ \\
\hline & & Geometric character c $c_{2}$ (score) & $\begin{array}{l}\text { Subjective index. Geometric character refers to the length, width and } \\
\text { height of a building. The higher the building, the greater the L/W, the } \\
\text { smaller the L/H, or the greater the H/W, the worse the overall stability } \\
\text { of the building, and the higher the risk level [35] }\end{array}$ \\
\hline & & Structure type $c_{3}$ (score) & $\begin{array}{l}\text { Subjective index. Different structure types have different ability to resist } \\
\text { external deformation. Their safety is mainly based on the structural } \\
\text { components bearing capacity, such as reinforced concrete }>\text { frame/ } \\
\text { shelf }>\text { concrete }>\text { brick/stone wood }>\text { wood structure, reinforced } \\
\text { concrete }>\text { plain concrete }>\text { brick/rubble stone foundation [30] }\end{array}$ \\
\hline
\end{tabular}

Deterioration degree $c_{4}$ (score) Subjective index. Most of the heritage buildings have a long history, and the structural components gradually suffer from aging and damage, which cannot reach the original carrying capacity. The higher the degradation degree [43], the higher the risk level is

Metro construction factors Cover depth $c_{5}(\mathrm{~m})$ $\left(b_{2}\right)$

Objective index. The deeper cover depth, the smaller the surface settlement is, and the lower the risk level is. There is an approximate linear relationship between the cover depth and surface settlement [20]. Generally, the cover depth of metro tunnel is above $6 \mathrm{~m}$ and below $30 \mathrm{~m}$, but there are other conditions (Chandpole Gate in Jaipur 4.5 m, Huaihai Middle Road station of Shanghai 33 m). The value range is set as $0 \mathrm{~m}-40 \mathrm{~m}$

Horizontal distance $c_{6}$ (m)

Tunnel diameter c7 (m)

Advancing speed $c_{8}(\mathrm{~mm} / \mathrm{min})$

Soil factors $\left(b_{3}\right)$

Friction angle $\mathrm{c}_{9}\left({ }^{\circ}\right)$

Compression modulus $\mathrm{C}_{10}$ (MPa)

Poisson's ratio $\mathrm{C}_{11}$

Soil loss ratio $\mathrm{C}_{12}(\%)$

Management factors $\left(b_{4}\right)$
Monitoring measurements $\mathrm{C}_{13}$ (score)
Objective index. When the metro interval structure side passage the existing structure, the monitoring range is within $30 \mathrm{~m}$ of the metro structure outer edge [44]. For heritage buildings, this distance can be appropriately increased. The value range is set as $0 \mathrm{~m}-40 \mathrm{~m}$

Objective index. The tunnel diameter is approximately equal to the diameter of the shield machine. At present, the shield tunneling machine used in the tunnel construction has a maximum size of Bertha from the United States with a diameter of $17.45 \mathrm{~m}$, used in The SR99 tunnel of Seattle, and the minimum size is Ruicheng from Jiangsu, China with a diameter of $2.1 \mathrm{~m}$, used in the sewage pipeline project of Nanjing. The typical metro tunnel is $6.2 \mathrm{~m} / 6.8 \mathrm{~m}$, but there are also $12.26 \mathrm{~m}$ (Dalian Metro Line 5) and $15.2 \mathrm{~m}$ (Wuhan Metro line 7). Considering all the existing dimensions, the value range is set as $0 \mathrm{~m}-20 \mathrm{~m}$

Objective index. The greater the advancing speed is, the greater the disturbance range to the soil, and the higher the risk level will be. Therefore, reducing the advancing speed is very important for the stability of the earth pressure around the shield [38]

Objective index. The friction angle increases, the surface settlement decreases, and the risk level decreases [40]. The interval value is found in the relevant literature [14]

Objective index. The compression modulus increases, the surface settlement decreases, and the risk level decreases [40]. interval value is found in the relevant literature [14]

Objective index. The Poisson's ratio increases, the surface settlement decreases, and the risk level decreases [20]. interval value is found in the relevant literature [14]

Objective index. The soil loss rate increases, the surface settlement increases, and the risk level increases [17]. Wei studied the value and distribution of soil loss rate caused by shield tunnel construction, which was $0.20 \%-3.01 \%$, and $95.77 \%$ of the data was distributed in the range of $0.20 \%-2.0 \%$ [41]

Subjective index. The Chinese code GB 50911-2013 specifies in detail the monitoring technical specifications for urban rail transit projects, including monitoring methods, monitoring technology, monitoring frequency and the arrangement of measuring points, etc. [45] 
Table 2 (continued)

\begin{tabular}{|c|c|c|c|}
\hline Target (0) & Criteria (B) & Index (C) & Description \\
\hline & & $\begin{array}{l}\text { Management system c } 14 \\
\text { (score) }\end{array}$ & $\begin{array}{l}\text { Subjective index. A sound production safety management system } \\
\text { includes the management system, management personnel, } \\
\text { division of duties, and management level. Perfect system, complete } \\
\text { personnel, clear division of responsibility, high management level } \\
\text { made strong guarantees for production safety }\end{array}$ \\
\hline & & $\begin{array}{l}\text { Contingency plan } c_{15} \\
\text { (score) }\end{array}$ & $\begin{array}{l}\text { Subjective index. The improvement of the contingency plan can } \\
\text { locate the hidden danger and weak link in time, and prepare for the } \\
\text { previously unpredicted danger, which has the value of early warning } \\
\text { and emergency }\end{array}$ \\
\hline & & Monitoring engineer $\mathrm{c}_{16}$ (score) & $\begin{array}{l}\text { Subjective index. Engineers with high professional level and rich } \\
\text { engineering experience are helpful to the reliability of monitoring } \\
\text { results. According to the feedback of monitoring results, the safety } \\
\text { status and development trend of engineering structures and } \\
\text { surrounding environment can be analyzed and predicted }\end{array}$ \\
\hline
\end{tabular}

(see Table 9) and the index layers (see Table 10). Equation (4) was used to construct the CWM decision matrix, as shown in Table 11.

Using MATLAB, the AHP weight matrix was calculated to be $W=\left[\begin{array}{llllll}0.0389 & 0.0077 & 0.0191 & 0.0838 & 0.0781\end{array}\right.$ $\begin{array}{llllllll}0.1267 & 0.0407 & 0.1168 & 0.0219 & 0.0675 & 0.0389 & 0.1198\end{array}$ $\left.\begin{array}{llll}0.0347 & 0.1095 & 0.0775 & 0.0185\end{array}\right]^{\mathrm{T}}$. Using Eqs. (4)-(7) in MATLAB, the CWM weight matrix was calculated to be $Z=\left[\begin{array}{llllll}0.1141 & 0.1031 & 0.0302 & 0.0316 & 0.0670 & 0.1271\end{array}\right.$ $\begin{array}{lllllll}0.0426 & 0.0550 & 0.0427 & 0.1024 & 0.0660 & 0.0631 & 0.0261\end{array}$ $\left.\begin{array}{llll}0.0110 & 0.0508 & 0.0673\end{array}\right]^{\mathrm{T}}$.

Using Eq. (8), $a$ is 0.3 in this project after repeated calculations, the comprehensive weight matrix was calculated to be $W^{\prime}=\left[\begin{array}{lll}0.0915 & 0.07450 .0269 & 0.04730 .0703\end{array}\right.$ $\begin{array}{lllllll}0.1270 & 0.0420 & 0.0735 & 0.0364 & 0.0919 & 0.0578 & 0.0801\end{array}$ $\left.\begin{array}{llllll}0.0287 & 0.0405 & 0.0588 & 0.0527\end{array}\right]^{\mathrm{T}}$.

\section{Correlation degree calculation}

The correlation degree of each evaluation factor with each level was calculated using Eqs. (9)-(13) (see Table 12). Moreover, using Eq. (14) and the comprehensive weight matrix, the average correlation degree $\mu_{j}(j=1,2, \ldots, 5)$ of the safety risk assessment level for the heritage building was calculated (see Table 13).

\section{Determination of risk level}

Equation $\mu_{k}=\max \left\{\mu_{j}\right\}, \mu_{k}=\mu_{3}$ was used to calculate the safety risk assessment level for the heritage building. It was found the safety impact upon the heritage building is at Level III when the shield tunneling machine travels at a speed of $40 \mathrm{~mm} / \mathrm{min}$ and at $3 \mathrm{~m}$ away from the nearest point of the building. The decision-makers would need to take essential pre-reinforcement measures before construction, such as grouting, mixing, rotary jet grouting and other general soil reinforcement measures; strengthen monitoring of surface subsidence and building displacement; and conduct trend analysis weekly for building damage caused by tunneling.

\section{Results}

During the propulsion process of the shield tunneling construction of the ZMLT, the risk levels were calculated between the building's different locations and different advancing speeds (see Table 14).

Table 14 shows the following results:

(1) When the advancing speed $\left(c_{8}\right)$ of the shield machine is in the low speed range $(20-35 \mathrm{~mm} /$ $\mathrm{min}$ ), the position of the shield machine relative to the heritage building (horizontal distance $c_{6}$ ) has no significant impact upon its safety; and the risk assessment level is II.

(2) When $c_{6}$ is unchanged, the safety risk to the heritage building becomes serious with increase of $c_{8}$.

(3) When $c_{6}$ is diverse, the safety risk is the same with changes to $c_{8}$. For example, the risk assessment level is IV for all of the following cases: $c_{6}=3 \mathrm{~m}, c_{8}=55 \mathrm{~mm} / \mathrm{min} ; c_{6}= \pm 6 \mathrm{~m}, c_{8}=60 \mathrm{~mm} /$ $\min ; c_{6}= \pm 10 \mathrm{~m}, c_{8}=65 \mathrm{~mm} / \mathrm{min} ;$ and $c_{6}=-15 \mathrm{~m}$, and $c_{8}=70 \mathrm{~mm} / \mathrm{min}$.

(4) When $c_{6}=-15 \mathrm{~m}$ and $c_{6}=15 \mathrm{~m}, c_{8}$ no longer has exactly the same influence on the safety, and its effect differs from other symmetrically horizontal distances to the heritage building. The main reason 
Table 3 Specific scoring details of each subjective index

\begin{tabular}{|c|c|c|c|c|c|c|c|c|}
\hline \multicolumn{2}{|c|}{ Index } & \multicolumn{2}{|c|}{ Content } & \multicolumn{5}{|c|}{ Grading (select one box per row) } \\
\hline \multirow[t]{4}{*}{$c_{1}$} & \multirow{4}{*}{$\begin{array}{l}\text { Impor- } \\
\text { tance degree } \\
(100)\end{array}$} & $x_{11}$ & $\begin{array}{l}\text { Cultural relics } \\
\text { level }(25)\end{array}$ & $\begin{array}{l}\text { Ungraded } \\
(0-5)\end{array}$ & $\begin{array}{l}\text { County } \\
(6-10)\end{array}$ & $\begin{array}{l}\text { Municipal } \\
(11-15)\end{array}$ & $\begin{array}{l}\text { Provincial } \\
(16-20)\end{array}$ & $\begin{array}{l}\text { National } \\
(21-25)\end{array}$ \\
\hline & & $x_{12}$ & $\begin{array}{l}\text { Historic value } \\
(25)\end{array}$ & $\begin{array}{l}\text { Very low } \\
(0-5)\end{array}$ & $\begin{array}{l}\text { Low } \\
(6-10)\end{array}$ & $\begin{array}{l}\text { Average } \\
(11-15)\end{array}$ & $\begin{array}{l}\text { High } \\
(16-20)\end{array}$ & $\begin{array}{l}\text { Very high } \\
(21-25)\end{array}$ \\
\hline & & $x_{13}$ & $\begin{array}{l}\text { Artistic value } \\
(25)\end{array}$ & $\begin{array}{l}\text { Very low } \\
(0-5)\end{array}$ & $\begin{array}{l}\text { Low } \\
(6-10)\end{array}$ & $\begin{array}{l}\text { Average } \\
(11-15)\end{array}$ & $\begin{array}{l}\text { High } \\
(16-20)\end{array}$ & $\begin{array}{l}\text { Very high } \\
(21-25)\end{array}$ \\
\hline & & $x_{14}$ & $\begin{array}{l}\text { Scientific value } \\
\text { (25) }\end{array}$ & $\begin{array}{l}\text { Very low } \\
(0-5)\end{array}$ & $\begin{array}{l}\text { Low } \\
(6-10)\end{array}$ & $\begin{array}{l}\text { Average } \\
(11-15)\end{array}$ & $\begin{array}{l}\text { High } \\
(16-20)\end{array}$ & $\begin{array}{l}\text { Very high } \\
(21-25)\end{array}$ \\
\hline \multirow[t]{4}{*}{$c_{2}$} & \multirow{4}{*}{$\begin{array}{l}\text { Geometric } \\
\text { character } \\
(100)\end{array}$} & $x_{21}$ & Height (25) & $\begin{array}{l}<5 \mathrm{~m} \\
(0-5)\end{array}$ & $\begin{array}{l}5-10 m \\
(6-10)\end{array}$ & $\begin{array}{l}10-15 \mathrm{~m} \\
(11-15)\end{array}$ & $\begin{array}{l}15-25 \mathrm{~m} \\
(16-20)\end{array}$ & $\begin{array}{l}>25 \mathrm{~m} \\
(21-25)\end{array}$ \\
\hline & & $x_{22}$ & $\begin{array}{l}\text { Length-width } \\
\text { ratio }(25)\end{array}$ & $\begin{array}{l}1.0-1.5 \\
(0-5)\end{array}$ & $\begin{array}{l}1.5-2.5 \\
(6-10)\end{array}$ & $\begin{array}{l}2.5-3.5 \\
(11-15)\end{array}$ & $\begin{array}{l}3.5-4.5 \\
(16-20)\end{array}$ & $\begin{array}{l}>4.5 \\
(21-25)\end{array}$ \\
\hline & & $x_{23}$ & $\begin{array}{l}\text { Length-height } \\
\text { ratio }(25)\end{array}$ & $\begin{array}{l}>5.0 \\
(0-5)\end{array}$ & $\begin{array}{l}3.0-5.0 \\
(6-10)\end{array}$ & $\begin{array}{l}1.0-3.0 \\
(11-15)\end{array}$ & $\begin{array}{l}0.5-1.0 \\
(16-20)\end{array}$ & $\begin{array}{l}<0.5 \\
(21-25)\end{array}$ \\
\hline & & $x_{24}$ & $\begin{array}{l}\text { height-width ratio } \\
\text { (25) }\end{array}$ & $\begin{array}{l}<0.5 \\
(0-5)\end{array}$ & $\begin{array}{l}0.5-1.0 \\
(6-10)\end{array}$ & $\begin{array}{l}1.0-1.5 \\
(11-15)\end{array}$ & $\begin{array}{l}1.5-2.0 \\
(16-20)\end{array}$ & $\begin{array}{l}2.0-2.5 \\
(21-25)\end{array}$ \\
\hline \multirow[t]{2}{*}{$c_{3}$} & \multirow[t]{2}{*}{$\begin{array}{l}\text { Structure type } \\
\text { (100) }\end{array}$} & $x_{31}$ & $\begin{array}{l}\text { Upper structure } \\
(50)\end{array}$ & $\begin{array}{l}\text { Wooden structure } \\
(0-10)\end{array}$ & $\begin{array}{l}\text { Brick/stone mix } \\
\text { structure } \\
(11-20)\end{array}$ & $\begin{array}{l}\text { Concrete structure } \\
(21-30)\end{array}$ & $\begin{array}{l}\text { Frame/bent } \\
\text { structure } \\
(31-40)\end{array}$ & $\begin{array}{l}\text { Reinforced con- } \\
\text { crete structure } \\
(41-50)\end{array}$ \\
\hline & & $x_{32}$ & $\begin{array}{l}\text { Foundation } \\
(50)\end{array}$ & $\begin{array}{l}\text { No foundation or } \\
\text { unknown } \\
(0-10)\end{array}$ & $\begin{array}{l}\text { Brick / rubble } \\
\text { foundation } \\
(11-20)\end{array}$ & $\begin{array}{l}\text { Plain concrete } \\
\text { foundation } \\
(21-30)\end{array}$ & $\begin{array}{l}\text { Reinforced concrete } \\
\text { foundation } \\
(31-40)\end{array}$ & $\begin{array}{l}\text { Pile foundation } \\
(41-50)\end{array}$ \\
\hline \multirow[t]{4}{*}{$C_{4}$} & \multirow[t]{4}{*}{$\begin{array}{l}\text { Deterioration } \\
\text { degree (100) }\end{array}$} & $x_{41}$ & $\begin{array}{l}\text { Deterioration } \\
(25)\end{array}$ & $\begin{array}{l}\text { No obvious } \\
\text { degradation } \\
(0-5)\end{array}$ & $\begin{array}{l}\text { Slight local } \\
\text { degradation } \\
(6-10)\end{array}$ & $\begin{array}{l}\text { Significant local } \\
\text { degradation } \\
(11-15)\end{array}$ & $\begin{array}{l}\text { Serious local } \\
\text { degradation } \\
(16-20)\end{array}$ & $\begin{array}{l}\text { Serious } \\
\text { degradation } \\
(21-25)\end{array}$ \\
\hline & & $x_{42}$ & $\begin{array}{l}\text { Weathering } \\
(25)\end{array}$ & $\begin{array}{l}\leq 5 \% \\
(0-5)\end{array}$ & $\begin{array}{l}5 \%-10 \% \\
(6-10)\end{array}$ & $\begin{array}{l}10 \%-15 \% \\
(11-15)\end{array}$ & $\begin{array}{l}15 \%-20 \% \\
(16-20)\end{array}$ & $\begin{array}{l}\geq 20 \% \\
(21-25)\end{array}$ \\
\hline & & $x_{43}$ & $\begin{array}{l}\text { Damage } \\
(25)\end{array}$ & $\begin{array}{l}\leq 1 \% \\
(0-5)\end{array}$ & $\begin{array}{l}\leq 10 \% \\
(6-10)\end{array}$ & $\begin{array}{l}10 \%-30 \% \\
(11-15)\end{array}$ & $\begin{array}{l}30 \%-50 \% \\
(16-20)\end{array}$ & $\begin{array}{l}\geq 50 \% \\
(21-25)\end{array}$ \\
\hline & & $x_{44}$ & $\begin{array}{l}\text { Crack width } \\
(25)\end{array}$ & $\begin{array}{l}0 \\
(0-5)\end{array}$ & $\frac{\leq 0.1 \mathrm{~mm}}{(6-10)}$ & $\begin{array}{l}0.1-0.3 \mathrm{~mm} \\
(11-15)\end{array}$ & $\begin{array}{l}0.3-0.5 \mathrm{~mm} \\
(16-20)\end{array}$ & $\begin{array}{l}\geq 0.5 \mathrm{~mm} \\
(21-25)\end{array}$ \\
\hline \multirow[t]{3}{*}{$c_{13}$} & \multirow[t]{3}{*}{$\begin{array}{l}\text { Monitoring } \\
\text { measurements } \\
(100)\end{array}$} & $x_{131}$ & $\begin{array}{l}\text { Monitoring } \\
\text { frequency } \\
(30)\end{array}$ & $\begin{array}{l}1 \text { time/ } \\
3-5 \text { days or no } \\
\text { monitoring } \\
(0-6)\end{array}$ & $\begin{array}{l}1-2 \text { times / } 1 \text { day } \\
(7-12)\end{array}$ & $\begin{array}{l}3-5 \text { times / } 1 \text { day } \\
(13-18)\end{array}$ & $\begin{array}{l}1 \text { time / 2-5 h } \\
\text { (19-24) }\end{array}$ & $\begin{array}{l}1-5 \text { times / } 1 \mathrm{~h} \\
(25-30)\end{array}$ \\
\hline & & $x_{132}$ & $\begin{array}{l}\text { Monitoring } \\
\text { precision } \\
(30)\end{array}$ & $\begin{array}{l}\text { Manual } \\
\quad \text { monitoring, } \\
\text { very low } \\
(0-6)\end{array}$ & $\begin{array}{l}\text { Manual } \\
\text { monitoring, } \\
\text { low } \\
(7-12)\end{array}$ & $\begin{array}{l}\text { Manual } \\
\quad \text { monitoring, } \\
\text { average } \\
(13-18)\end{array}$ & $\begin{array}{l}\text { Automated } \\
\text { monitoring } \\
\text { high } \\
(19-24)\end{array}$ & $\begin{array}{l}\text { Automated } \\
\text { monitoring, } \\
\text { very high } \\
(25-30)\end{array}$ \\
\hline & & $x_{133}$ & $\begin{array}{l}\text { Measuring point } \\
(40)\end{array}$ & $\begin{array}{l}\text { Very lack } \\
(0-8)\end{array}$ & $\begin{array}{l}\text { Lack } \\
(9-16)\end{array}$ & $\begin{array}{l}\text { Average } \\
(17-24)\end{array}$ & $\begin{array}{l}\text { Dense } \\
(25-32)\end{array}$ & $\begin{array}{l}\text { Very dense } \\
(33-40)\end{array}$ \\
\hline \multirow[t]{4}{*}{$c_{14}$} & \multirow[t]{4}{*}{$\begin{array}{l}\text { Management } \\
\text { system (100) }\end{array}$} & $x_{141}$ & $\begin{array}{c}\text { Management } \\
\text { system }(25)\end{array}$ & $\begin{array}{l}\text { Worst } \\
(0-5)\end{array}$ & $\begin{array}{l}\text { Poor } \\
(6-10)\end{array}$ & $\begin{array}{l}\text { Average } \\
(11-15)\end{array}$ & $\begin{array}{l}\text { Good } \\
(16-20)\end{array}$ & $\begin{array}{l}\text { Perfect } \\
(21-25)\end{array}$ \\
\hline & & $x_{142}$ & $\begin{array}{l}\text { Management } \\
\text { personnel (25) }\end{array}$ & $\begin{array}{l}\text { Worst } \\
(0-5)\end{array}$ & $\begin{array}{l}\text { Poor } \\
(6-10)\end{array}$ & $\begin{array}{l}\text { Average } \\
(11-15)\end{array}$ & $\begin{array}{l}\text { Good } \\
(16-20)\end{array}$ & $\begin{array}{l}\text { Perfect } \\
(21-25)\end{array}$ \\
\hline & & $x_{143}$ & $\begin{array}{l}\text { Responsibility } \\
\text { division (25) }\end{array}$ & $\begin{array}{l}\text { Worst } \\
(0-5)\end{array}$ & $\begin{array}{l}\text { Poor } \\
(6-10)\end{array}$ & $\begin{array}{l}\text { Average } \\
(11-15)\end{array}$ & $\begin{array}{l}\text { Good } \\
(16-20)\end{array}$ & $\begin{array}{l}\text { Perfect } \\
(21-25)\end{array}$ \\
\hline & & $x_{144}$ & $\begin{array}{l}\text { Management level } \\
(25)\end{array}$ & $\begin{array}{l}\text { Very low } \\
(0-5)\end{array}$ & $\begin{array}{l}\text { LOW } \\
(6-10)\end{array}$ & $\begin{array}{l}\text { Average } \\
(11-15)\end{array}$ & $\begin{array}{l}\text { High } \\
(16-20)\end{array}$ & $\begin{array}{l}\text { Very high } \\
(21-25)\end{array}$ \\
\hline \multirow[t]{2}{*}{$C_{15}$} & \multirow[t]{2}{*}{$\begin{array}{l}\text { Contingency } \\
\text { plan (100) }\end{array}$} & $x_{151}$ & $\begin{array}{l}\text { Emergency plan } \\
\quad(50)\end{array}$ & $\begin{array}{l}\text { Worst } \\
(0-10)\end{array}$ & $\begin{array}{l}\text { Poor } \\
(11-20)\end{array}$ & $\begin{array}{l}\text { Average } \\
(21-30)\end{array}$ & $\begin{array}{l}\text { Good } \\
(31-40)\end{array}$ & $\begin{array}{l}\text { Ideal } \\
(41-50)\end{array}$ \\
\hline & & $x_{152}$ & $\begin{array}{l}\text { Early warning } \\
\text { response }(50)\end{array}$ & $\begin{array}{l}\text { Very slow } \\
(0-10)\end{array}$ & $\begin{array}{l}\text { Slow } \\
(11-20)\end{array}$ & $\begin{array}{l}\text { Average } \\
(21-30)\end{array}$ & $\begin{array}{l}\text { Fast } \\
(31-40)\end{array}$ & $\begin{array}{l}\text { Very fast } \\
(41-50)\end{array}$ \\
\hline \multirow[t]{2}{*}{$c_{16}$} & \multirow{2}{*}{$\begin{array}{l}\text { Monitoring } \\
\text { engineer } \\
(100)\end{array}$} & $x_{161}$ & $\begin{array}{l}\text { Professional level } \\
\quad(50)\end{array}$ & $\begin{array}{l}\text { Very low } \\
(0-10)\end{array}$ & $\begin{array}{l}\text { Low } \\
(11-20)\end{array}$ & $\begin{array}{l}\text { Average } \\
(21-30)\end{array}$ & $\begin{array}{l}\text { High } \\
(31-40)\end{array}$ & $\begin{array}{l}\text { Very high } \\
(41-50)\end{array}$ \\
\hline & & $x_{162}$ & $\begin{array}{l}\text { Practical } \\
\quad \text { experience (50) }\end{array}$ & $\begin{array}{l}\text { very low } \\
(0-10)\end{array}$ & $\begin{array}{l}\text { low } \\
(11-20)\end{array}$ & $\begin{array}{l}\text { average } \\
(21-30)\end{array}$ & $\begin{array}{l}\text { high } \\
(31-40)\end{array}$ & $\begin{array}{l}\text { very high } \\
(41-50)\end{array}$ \\
\hline
\end{tabular}


Table 4 Evaluation criteria for each index

\begin{tabular}{|c|c|c|c|c|c|c|}
\hline Evaluation factor & Attribute category & I & II & III & IV & $\mathbf{V}$ \\
\hline$c_{1}$ & Negative index & $0-20$ & $20-40$ & $40-60$ & $60-80$ & $80-100$ \\
\hline$c_{2}$ & Negative index & $0-20$ & $20-40$ & $40-60$ & $60-80$ & $80-100$ \\
\hline$c_{3}$ & Positive index & $80-100$ & $60-80$ & $40-60$ & $20-40$ & $0-20$ \\
\hline$C_{4}$ & Negative index & $0-20$ & $20-40$ & $40-60$ & $60-80$ & $80-100$ \\
\hline$c_{5}$ & Positive index & $32-40$ & $24-32$ & $16-24$ & $8-16$ & $0-8$ \\
\hline$c_{6}$ & Positive index & $32-40$ & $24-32$ & $16-24$ & $8-16$ & $0-8$ \\
\hline$C_{7}$ & Negative index & $0-4$ & $4-8$ & $8-12$ & $12-16$ & $16-20$ \\
\hline$C_{8}$ & Negative index & $0-20$ & $20-40$ & $40-60$ & $60-80$ & $80-100$ \\
\hline$C_{9}$ & Positive index & $20-30$ & $15-20$ & $10-15$ & $5-10$ & $0-5$ \\
\hline$c_{10}$ & Positive index & $16-20$ & $12-16$ & $8-12$ & $4-8$ & $0-4$ \\
\hline$c_{11}$ & Positive index & $0.4-0.5$ & $0.3-0.4$ & $0.2-0.3$ & $0.1-0.2$ & $0-0.1$ \\
\hline$c_{12}$ & Negative index & $0-0.5$ & $0.5-1.0$ & $1.0-1.5$ & $1.5-2.0$ & $2.0-3.0$ \\
\hline$c_{13}$ & Positive index & $80-100$ & $60-80$ & $40-60$ & $20-40$ & $0-20$ \\
\hline$c_{14}$ & Positive index & $80-100$ & $60-80$ & $40-60$ & $20-40$ & $0-20$ \\
\hline$C_{15}$ & Positive index & $80-100$ & $60-80$ & $40-60$ & $20-40$ & $0-20$ \\
\hline$c_{16}$ & Positive index & $80-100$ & $60-80$ & $40-60$ & $20-40$ & $0-20$ \\
\hline
\end{tabular}

Table 5 Normalized evaluation criteria of each index

\begin{tabular}{lllllll}
\hline Evaluation factor & $\begin{array}{l}\text { Attribute } \\
\text { category }\end{array}$ & I & II & III & IV & V \\
\hline$c_{1}$ & - & $0.0000-0.2000$ & $0.2000-0.4000$ & $0.4000-0.6000$ & $0.6000-0.8000$ & $0.8000-1.0000$ \\
$c_{2}$ & - & $0.0000-0.2000$ & $0.2000-0.4000$ & $0.4000-0.6000$ & $0.6000-0.8000$ & $0.8000-1.0000$ \\
$c_{3}$ & + & $0.0000-0.2000$ & $0.2000-0.4000$ & $0.4000-0.6000$ & $0.6000-0.8000$ & $0.8000-1.0000$ \\
$c_{4}$ & - & $0.0000-0.2000$ & $0.2000-0.4000$ & $0.4000-0.6000$ & $0.6000-0.8000$ & $0.8000-1.0000$ \\
$c_{5}$ & + & $0.0000-0.2000$ & $0.2000-0.4000$ & $0.4000-0.6000$ & $0.6000-0.8000$ & $0.8000-1.0000$ \\
$c_{6}$ & + & $0.0000-0.2000$ & $0.2000-0.4000$ & $0.4000-0.6000$ & $0.6000-0.8000$ & $0.8000-1.0000$ \\
$c_{7}$ & - & $0.0000-0.2000$ & $0.2000-0.4000$ & $0.4000-0.6000$ & $0.6000-0.8000$ & $0.8000-1.0000$ \\
$c_{8}$ & - & $0.0000-0.2000$ & $0.2000-0.4000$ & $0.4000-0.6000$ & $0.6000-0.8000$ & $0.8000-1.0000$ \\
$c_{9}$ & + & $0.0000-0.3333$ & $0.3333-0.5000$ & $0.5000-0.6667$ & $0.6667-0.8333$ & $0.8333-1.0000$ \\
$c_{10}$ & + & $0.0000-0.2000$ & $0.2000-0.4000$ & $0.4000-0.6000$ & $0.6000-0.8000$ & $0.8000-1.0000$ \\
$c_{11}$ & + & $0.0000-0.2000$ & $0.2000-0.4000$ & $0.4000-0.6000$ & $0.6000-0.8000$ & $0.8000-1.0000$ \\
$c_{12}$ & - & $0.0000-0.1667$ & $0.1667-0.3333$ & $0.3333-0.5000$ & $0.5000-0.6667$ & $0.6667-1.0000$ \\
$c_{13}$ & + & $0.0000-0.2000$ & $0.2000-0.4000$ & $0.4000-0.6000$ & $0.6000-0.8000$ & $0.8000-1.0000$ \\
$c_{14}$ & + & $0.0000-0.2000$ & $0.2000-0.4000$ & $0.4000-0.6000$ & $0.6000-0.8000$ & $0.8000-1.0000$ \\
$c_{15}$ & + & $0.0000-0.2000$ & $0.2000-0.4000$ & $0.4000-0.6000$ & $0.6000-0.8000$ & $0.8000-1.0000$ \\
$c_{16}$ & + & $0.0000-0.2000$ & $0.2000-0.4000$ & $0.4000-0.6000$ & $0.6000-0.8000$ & $0.8000-1.0000$ \\
\hline
\end{tabular}

behind is the difference in geological conditions at $\pm 15 \mathrm{~m}$.

(5) When $c_{6}=25 \mathrm{~m}, c_{8}$ has little influence on safety; the levels are all at II. This finding is consistent with relevant standard requirements [44]. That is, when a metro structure or pipeline runs alongside an existing structure, the monitoring range is gener- ally within $30 \mathrm{~m}$ of both sides of the metro structure and the pipeline.

\section{Discussion}

Comparison analysis

In order to further verify the feasibility of the SPA method proposed in this research, the Matter-Element 


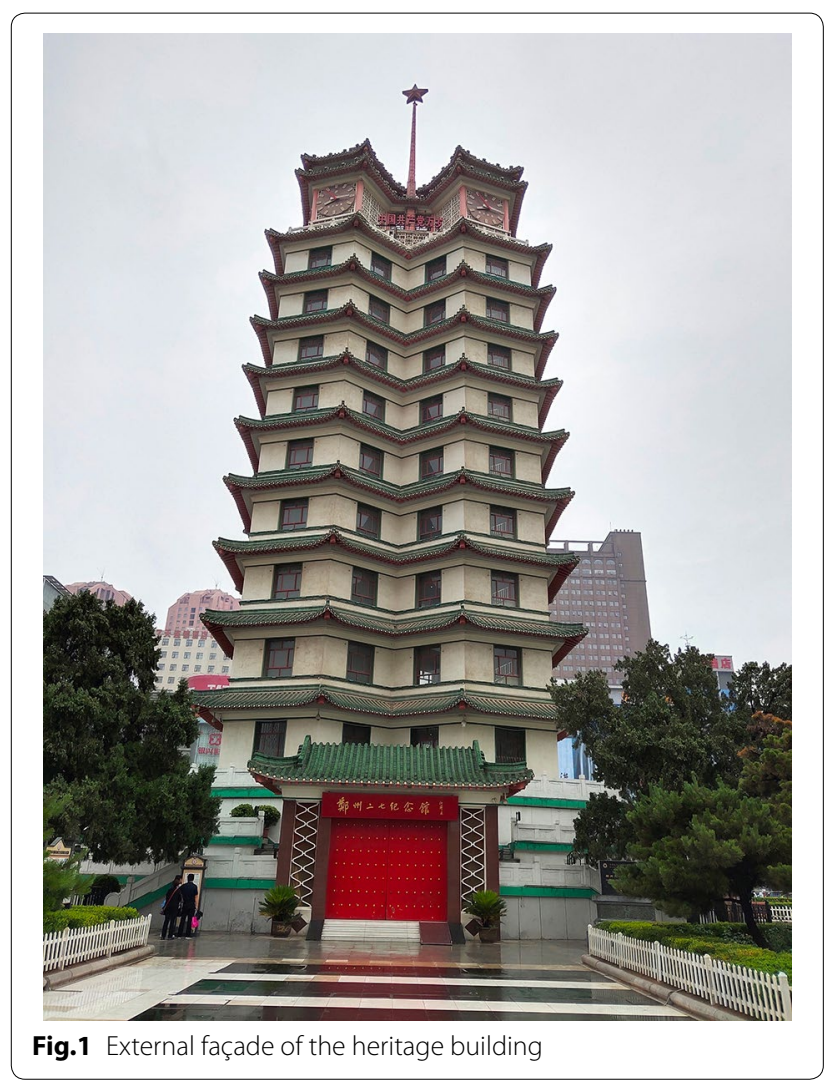

(ME) method, based on the extension mathematics theory [28], was also used to calculate and compare the evaluation results collected from the above case study. Figure 4 shows the comparison results:

(1) The variation trend calculated by the two evaluation methods was the same. The levels calculated by SPA and ME were distributed between II and IV. When $c_{6}$ is unchanged, the risk level increases with the increase of $c_{8}$; when $c_{8}$ is unchanged, the risk level increases with the increase of $c_{6}$.

(2) The results calculated by the two evaluation methods are slightly different. Most of the results calculated by SPA are higher than ME. This indicates that this method is more conservative and conducive to the protection of heritage buildings. Except when $c_{6}=-25 \mathrm{~m}$, and $c_{8} \geq 70$, ME (III) is higher than SPA (II), showing SPA is more aligned with the actual situation. However, owing to their different data processing, the deviation is inevitable, which is acceptable when a large number of buildings need to be evaluated [15].

\section{Implementation effects}

The SPA evaluation method needs to be conducted before the construction. Decision-makers can apply the

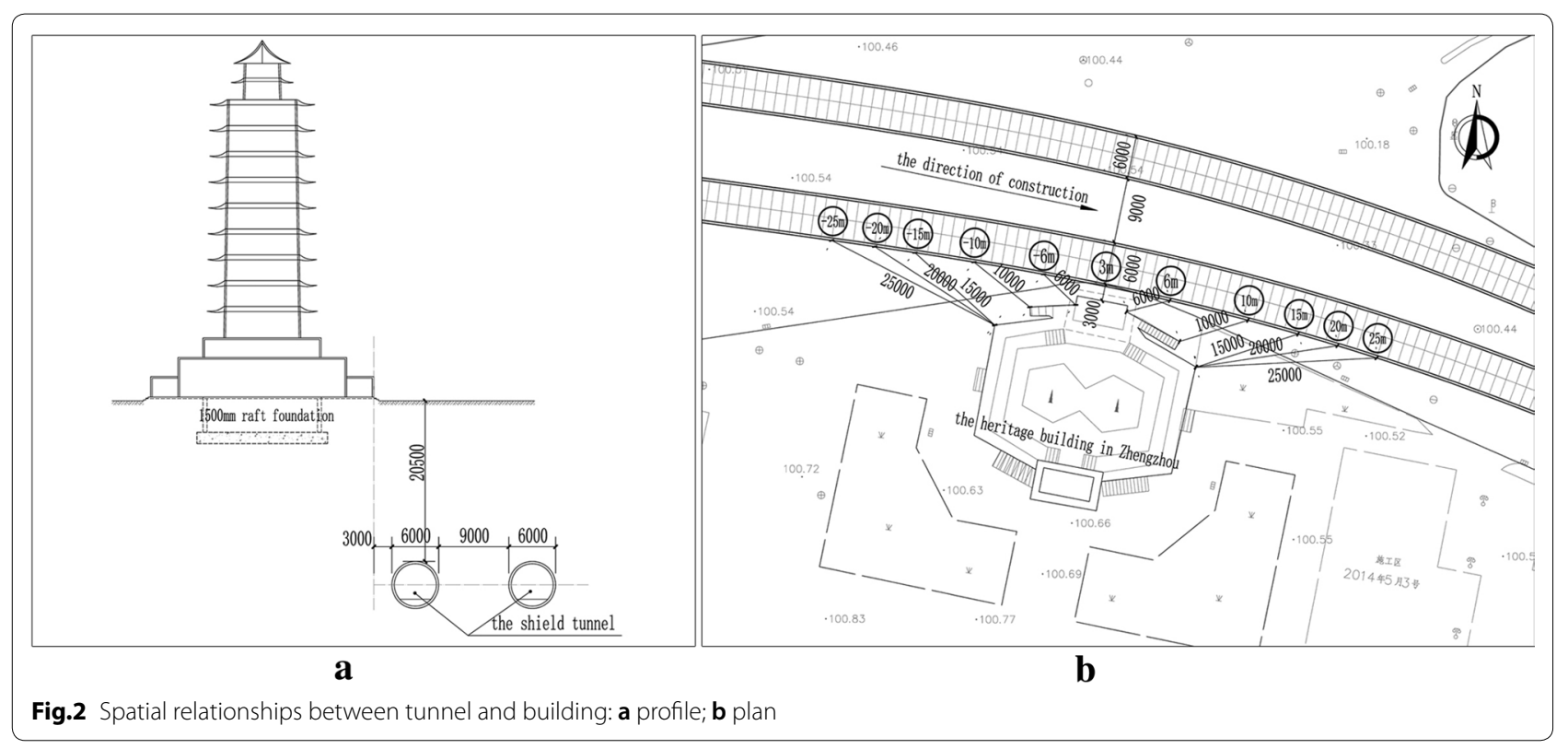




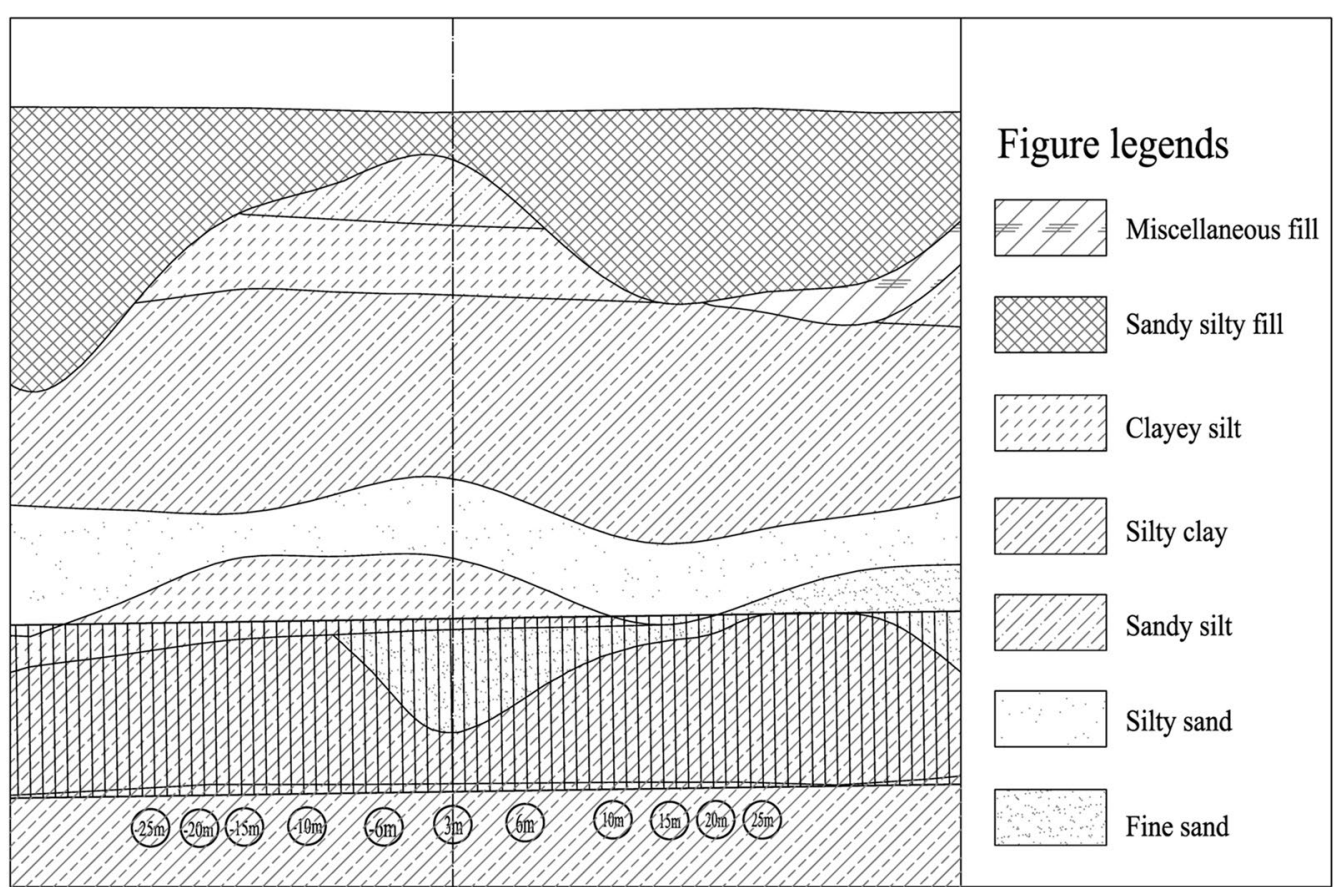

Fig.3 The engineering geological section

Table 6 Values of 16 evaluation indexes

\begin{tabular}{|c|c|c|c|c|c|c|c|c|c|c|c|c|c|c|c|c|}
\hline Index & $c_{1}$ & $c_{2}$ & $c_{3}$ & $c_{4}$ & $c_{5}$ & $c_{6}$ & $c_{7}$ & $c_{8}$ & $c_{9}$ & $c_{10}$ & $c_{11}$ & $c_{12}$ & $c_{13}$ & $c_{14}$ & $c_{15}$ & $c_{16}$ \\
\hline$-25 m$ & 83 & 75 & 78 & 23 & 20.9 & 25 & 6.2 & - & 19 & 4.6 & 0.33 & 1.06 & 81 & 92 & 63 & 51 \\
\hline$-20 m$ & 83 & 75 & 78 & 23 & 20.82 & 20 & 6.2 & - & 18 & 5.5 & 0.29 & 1.06 & 81 & 92 & 63 & 51 \\
\hline$-15 m$ & 83 & 75 & 78 & 23 & 20.77 & 15 & 6.2 & - & 19 & 5.3 & 0.33 & 1.05 & 81 & 92 & 63 & 51 \\
\hline$-10 m$ & 83 & 75 & 78 & 23 & 20.68 & 10 & 6.2 & - & 18 & 5.9 & 0.28 & 1.05 & 81 & 92 & 63 & 51 \\
\hline$-6 m$ & 83 & 75 & 78 & 23 & 20.57 & 6 & 6.2 & - & 18 & 6.3 & 0.28 & 1.27 & 81 & 92 & 63 & 51 \\
\hline $3 \mathrm{~m}$ & 83 & 75 & 78 & 23 & 20.5 & 3 & 6.2 & - & 19 & 5.1 & 0.26 & 1.31 & 81 & 92 & 63 & 51 \\
\hline $6 \mathrm{~m}$ & 83 & 75 & 78 & 23 & 20.42 & 6 & 6.2 & - & 18 & 6.1 & 0.28 & 1.28 & 81 & 92 & 63 & 51 \\
\hline $10 \mathrm{~m}$ & 83 & 75 & 78 & 23 & 20.3 & 10 & 6.2 & - & 18 & 5.9 & 0.30 & 1.18 & 81 & 92 & 63 & 51 \\
\hline $15 \mathrm{~m}$ & 83 & 75 & 78 & 23 & 20.23 & 15 & 6.2 & - & 18 & 4.2 & 0.32 & 1.12 & 81 & 92 & 63 & 51 \\
\hline $20 \mathrm{~m}$ & 83 & 75 & 78 & 23 & 20.18 & 20 & 6.2 & - & 18 & 5.5 & 0.29 & 1.11 & 81 & 92 & 63 & 51 \\
\hline $25 \mathrm{~m}$ & 83 & 75 & 78 & 23 & 20.1 & 25 & 6.2 & - & 19 & 4.5 & 0.34 & 1.05 & 81 & 92 & 63 & 51 \\
\hline
\end{tabular}

evaluation results into the safety control measures. If the risk assessment results are at Level-I or Level-II, reinforcement measures do not need to be taken before construction (see Table 1). When the assessment results are higher than Level III, reinforcement measures should be undertaken to control the high level of risk.

In the actual construction of this project, the advancing speed of the shield machine was normally at
$60 \mathrm{~mm} / \mathrm{min}$. Table 14 shows that metro shield construction has a very high impact on the structural safety of heritage buildings at this speed. It was found to reduce the impact on the structure of this building while optimizing the metro construction schedule, when $c_{6}<6 \mathrm{~m}$, the speed should not exceed $50 \mathrm{~mm} / \mathrm{min}$; when $c_{6}=$ 6-15 m, the speed should not exceed $60 \mathrm{~mm} / \mathrm{min}$; when $c_{6}>15 \mathrm{~m}$, the shield construction could be done 
Table 7 Values of 16 normalized evaluation indexes

\begin{tabular}{|c|c|c|c|c|c|c|c|c|c|c|c|c|c|c|c|c|}
\hline Index & $c_{1}$ & $c_{2}$ & $c_{3}$ & $c_{4}$ & $c_{5}$ & $c_{6}$ & $c_{7}$ & $c_{8}$ & $C_{9}$ & $c_{10}$ & $c_{11}$ & $c_{12}$ & $c_{13}$ & $c_{14}$ & $c_{15}$ & $c_{16}$ \\
\hline$-25 m$ & 0.83 & 0.75 & 0.22 & 0.23 & 0.4775 & 0.3750 & 0.31 & - & 0.3667 & 0.7700 & 0.3400 & 0.3533 & 0.19 & 0.08 & 0.37 & 0.49 \\
\hline$-20 m$ & 0.83 & 0.75 & 0.22 & 0.23 & 0.4795 & 0.5000 & 0.31 & - & 0.4000 & 0.7250 & 0.4200 & 0.3533 & 0.19 & 0.08 & 0.37 & 0.49 \\
\hline$-15 m$ & 0.83 & 0.75 & 0.22 & 0.23 & 0.4808 & 0.6250 & 0.31 & - & 0.3667 & 0.7350 & 0.3400 & 0.3500 & 0.19 & 0.08 & 0.37 & 0.49 \\
\hline$-10 m$ & 0.83 & 0.75 & 0.22 & 0.23 & 0.4830 & 0.7500 & 0.31 & - & 0.4000 & 0.7050 & 0.4400 & 0.3500 & 0.19 & 0.08 & 0.37 & 0.49 \\
\hline$-6 m$ & 0.83 & 0.75 & 0.22 & 0.23 & 0.4858 & 0.8500 & 0.31 & - & 0.4000 & 0.6850 & 0.4400 & 0.4233 & 0.19 & 0.08 & 0.37 & 0.49 \\
\hline $3 \mathrm{~m}$ & 0.83 & 0.75 & 0.22 & 0.23 & 0.4875 & 0.9250 & 0.31 & - & 0.3667 & 0.7450 & 0.4800 & 0.4367 & 0.19 & 0.08 & 0.37 & 0.49 \\
\hline $6 \mathrm{~m}$ & 0.83 & 0.75 & 0.22 & 0.23 & 0.4895 & 0.8500 & 0.31 & - & 0.4000 & 0.6950 & 0.4400 & 0.4267 & 0.19 & 0.08 & 0.37 & 0.49 \\
\hline $10 \mathrm{~m}$ & 0.83 & 0.75 & 0.22 & 0.23 & 0.4925 & 0.7500 & 0.31 & - & 0.4000 & 0.7050 & 0.4000 & 0.3933 & 0.19 & 0.08 & 0.37 & 0.49 \\
\hline $15 \mathrm{~m}$ & 0.83 & 0.75 & 0.22 & 0.23 & 0.4942 & 0.6250 & 0.31 & - & 0.4000 & 0.7900 & 0.3600 & 0.3733 & 0.19 & 0.08 & 0.37 & 0.49 \\
\hline $20 \mathrm{~m}$ & 0.83 & 0.75 & 0.22 & 0.23 & 0.4955 & 0.5000 & 0.31 & - & 0.4000 & 0.7250 & 0.4200 & 0.3700 & 0.19 & 0.08 & 0.37 & 0.49 \\
\hline $25 \mathrm{~m}$ & 0.83 & 0.75 & 0.22 & 0.23 & 0.4975 & 0.3750 & 0.31 & - & 0.3667 & 0.7750 & 0.3200 & 0.3500 & 0.19 & 0.08 & 0.37 & 0.49 \\
\hline
\end{tabular}

Table 8 The 1-9 scale for comparison of two factors [46]

\begin{tabular}{lll}
\hline Intensity of importance & Definition & Explanation \\
\hline 1 & Equal importance & A is as equally important as B \\
3 & Moderate importance & A is moderate important than B \\
5 & Strong importance & A is strong important than B \\
7 & Very strong importance & A is very strong important than B \\
9 & Extreme importance & A is extreme important than B \\
$2,4,6,8$ & Compromise & The importance of A over B is in the middle of the above adjacent judgments \\
$1 / 2,1 / 3, \ldots, 1 / 9$ & Unimportance & If A has one of the above nonzero numbers assigned to it when compared \\
& with B, then B has the reciprocal value when compared with A \\
\hline
\end{tabular}

Table 9 Judgment matrix of criterion layer

\begin{tabular}{lllll}
\hline $\mathbf{0}$ & $\boldsymbol{b}_{\mathbf{1}}$ & $\boldsymbol{b}_{\mathbf{2}}$ & $\boldsymbol{b}_{\mathbf{3}}$ & $\boldsymbol{b}_{\mathbf{4}}$ \\
\hline$b_{1}$ & 1 & $1 / 3$ & 1 & $1 / 2$ \\
$b_{2}$ & 3 & 1 & 2 & 1 \\
$b_{3}$ & 1 & $1 / 2$ & 1 & 2 \\
$b_{4}$ & 2 & 1 & $1 / 2$ & 1 \\
\hline
\end{tabular}

at the normal advancing speed of $60 \mathrm{~mm} / \mathrm{min}$. Furthermore, it was found that additional reinforcement measures are required before construction. For example, 29-m-length ø800@1000 mm isolation piles between the building and the metro tunnel need to be installed to form an isolation curtain to limit deformation of the soil mass behind the piles [47]. During construction, the monitoring of surface subsidence and building

Table 10 Judgment matrixes of index layer

\begin{tabular}{|c|c|c|c|c|c|c|c|c|c|}
\hline$b_{1}$ & $c_{1}$ & $c_{2}$ & $c_{3}$ & $c_{4}$ & $b_{2}$ & $c_{5}$ & $c_{6}$ & $c_{7}$ & $c_{8}$ \\
\hline$c_{1}$ & 1 & 5 & 3 & $1 / 3$ & $c_{5}$ & 1 & $1 / 2$ & 3 & $1 / 2$ \\
\hline$c_{2}$ & $1 / 5$ & 1 & $1 / 4$ & $1 / 7$ & $c_{6}$ & 2 & 1 & 3 & 1 \\
\hline$c_{3}$ & $1 / 3$ & 4 & 1 & $1 / 5$ & $C_{7}$ & $1 / 3$ & $1 / 3$ & 1 & $1 / 2$ \\
\hline$C_{4}$ & 3 & 7 & 5 & 1 & $c_{8}$ & 2 & 1 & 2 & 1 \\
\hline $\boldsymbol{b}_{3}$ & $c_{9}$ & $c_{10}$ & $c_{11}$ & $c_{12}$ & $\boldsymbol{b}_{4}$ & $c_{13}$ & $c_{14}$ & $c_{15}$ & $c_{16}$ \\
\hline$C_{9}$ & 1 & $1 / 3$ & $1 / 2$ & $1 / 5$ & $c_{13}$ & 1 & $1 / 3$ & $1 / 4$ & 3 \\
\hline$c_{10}$ & 3 & 1 & 2 & $1 / 2$ & $c_{14}$ & 3 & 1 & 2 & 5 \\
\hline$c_{11}$ & 2 & $1 / 2$ & 1 & $1 / 3$ & $c_{15}$ & 4 & $1 / 2$ & 1 & 3 \\
\hline$c_{12}$ & 5 & 2 & 3 & 1 & $c_{16}$ & $1 / 3$ & $1 / 5$ & $1 / 3$ & 1 \\
\hline
\end{tabular}


Table 11 Decision matrix of CWM

\begin{tabular}{|c|c|c|c|c|c|c|c|c|c|c|c|c|c|c|c|c|}
\hline$x_{i j}$ & $c_{1}$ & $c_{2}$ & $c_{3}$ & $c_{4}$ & $c_{5}$ & $c_{6}$ & $c_{7}$ & $c_{8}$ & $c_{9}$ & $c_{10}$ & $c_{11}$ & $c_{12}$ & $c_{13}$ & $c_{14}$ & $c_{15}$ & $c_{16}$ \\
\hline | & 0.20 & 0.20 & 0.20 & 0.20 & 0.20 & 0.20 & 0.20 & 0.20 & 0.3333 & 0.20 & 0.20 & 0.1667 & 0.20 & 0.20 & 0.20 & 0.20 \\
\hline ॥ & 0.40 & 0.40 & 0.40 & 0.40 & 0.40 & 0.40 & 0.40 & 0.40 & 0.5000 & 0.40 & 0.40 & 0.3333 & 0.40 & 0.40 & 0.40 & 0.40 \\
\hline III & 0.60 & 0.60 & 0.60 & 0.60 & 0.60 & 0.60 & 0.60 & 0.60 & 0.6667 & 0.60 & 0.60 & 0.5000 & 0.60 & 0.60 & 0.60 & 0.60 \\
\hline IV & 0.80 & 0.80 & 0.80 & 0.80 & 0.80 & 0.80 & 0.80 & 0.80 & 0.8333 & 0.80 & 0.80 & 0.6667 & 0.80 & 0.80 & 0.80 & 0.80 \\
\hline V & 1.00 & 1.00 & 1.00 & 1.00 & 1.00 & 1.00 & 1.00 & 1.00 & 1.0000 & 1.00 & 1.00 & 1.0000 & 1.00 & 1.00 & 1.00 & 1.00 \\
\hline
\end{tabular}

Table 12 Correlation degree of each evaluation factor with each level

\begin{tabular}{llllll}
\hline $\begin{array}{l}\text { Evaluation } \\
\text { factor }\end{array}$ & I & II & III & IV & V \\
\hline$c_{1}$ & -1 & -1 & -1 & 0.7 & 1 \\
$c_{2}$ & -1 & -1 & -0.5 & 1 & 0.5 \\
$c_{3}$ & 0.8 & 1 & -0.8 & -1 & -1 \\
$c_{4}$ & 0.7 & 1 & -0.7 & -1 & -1 \\
$c_{5}$ & -1 & 0.125 & 1 & -0.125 & -1 \\
$c_{6}$ & -1 & -1 & -1 & -0.25 & 1 \\
$c_{7}$ & -0.1 & 1 & 0.1 & -1 & -1 \\
$c_{8}$ & -1 & 1 & 1 & -1 & -1 \\
$c_{9}$ & 0.6 & 1 & -0.6 & -1 & -1 \\
$c_{10}$ & -1 & -1 & -0.45 & 1 & 0.45 \\
$c_{11}$ & -1 & 0.2 & 1 & -0.2 & -1 \\
$c_{12}$ & -1 & -0.24 & 1 & 0.24 & -1 \\
$c_{13}$ & 1 & 0.9 & -1 & -1 & -1 \\
$c_{14}$ & 1 & -0.2 & -1 & -1 & -1 \\
$c_{15}$ & -0.7 & 1 & 0.7 & -1 & -1 \\
$c_{16}$ & -1 & 0.1 & 1 & -0.1 & -1 \\
\hline
\end{tabular}

Table 13 Average correlation degree of each risk assessment level

\begin{tabular}{llllll}
\hline Level & I & II & III & IV & V \\
\hline$\mu_{j}$ & -0.6190 & -0.0758 & -0.0629 & -0.1619 & -0.3181 \\
\hline
\end{tabular}

displacement should be strengthened. Figure 5 shows the layout of on-site monitoring points. For example, it shows the shield cutter head moved into the $30 \mathrm{~m}$ scope of the building on April 15, 2019, and the shield tail moved away from the $30 \mathrm{~m}$ scope on April 29, 2019. The monitoring data for the surface subsidence are shown in Fig. 6a, and building displacement data are shown in Fig. 6b. The monitoring results show that the surface subsidence is $4.87-4.79 \mathrm{~mm}$; the maximum differential settlement of the building is $1.89 \mathrm{~mm}$; and the gradient $\approx 0.13 \%$, conforming to the relevant control standards [30, 45]. After the construction, no visible cracks or uneven settlement occurred on the outdoor floor of the building (see Fig. 7a); no visible cracks appeared in the main structure (see Fig. 7b); a few slight cracks appeared in the non-structural components (see Fig. 7c); and a door tilted slightly (see Fig. 7d).

The above findings show that the evaluation results are aligned with the actual physical results, and that risk control was effectively carried out by taking protective measures and controlling the related parameters.

\section{Conclusions}

This study has developed a safety risk assessment model to investigate the impact of the metro construction on adjacent heritage buildings. The model is based upon the SPA theory and uses 16 single indexes as evaluation factors, namely, importance degree, geometric character, structure type, deterioration degree, cover depth, horizontal distance, tunnel diameter, advancing speed, friction angle, compression modulus, Poisson's ratio, soil loss ratio, monitoring measurements, management system, contingency plan, and monitoring engineer. The model was used in a case study of a heritage building in Zhengzhou, and the main conclusions are as follows.

(1) The SPA-based safety risk assessment model improves the information utilization rate and enhances the credibility of the evaluation results. Therefore, the method is suitable for multi-level and multi-objective complex decision systems.

(2) In general, when metro lines go through old cities, a large number of heritage buildings are affected. Commonly used numerical simulation methods have high precision. However, the process is very time-consuming if every building has to be included in the calculations. The proposed SPA method is 
Table 14 Summary sheet of the evaluation results

\begin{tabular}{c|cccccccccccccccc}
\hline$c_{8}$ & $\mathbf{2 0}$ & $\mathbf{2 5}$ & $\mathbf{3 0}$ & $\mathbf{3 5}$ & $\mathbf{4 0}$ & $\mathbf{4 5}$ & $\mathbf{5 0}$ & $\mathbf{5 5}$ & $\mathbf{6 0}$ & $\mathbf{6 5}$ & $\mathbf{7 0}$ & $\mathbf{7 5}$ & $\mathbf{8 0}$ & $\mathbf{8 5}$ & $\mathbf{9 0}$ \\
\hline$-25 \mathrm{~m}$ & II & II & II & II & II & II & II & II & II & II & II & II & II & II & II \\
$-20 \mathrm{~m}$ & II & II & II & II & III & III & III & III & III & III & III & III & III & III & III \\
$-15 \mathrm{~m}$ & II & II & II & II & III & III & III & III & III & III & IV & IV & IV & IV & IV \\
$-10 \mathrm{~m}$ & II & II & II & II & III & III & III & III & III & IV & IV & IV & IV & IV & IV \\
$-6 \mathrm{~m}$ & II & II & II & II & III & III & III & III & IV & IV & IV & IV & IV & IV & IV \\
$3 \mathrm{~m}$ & II & II & II & II & III & III & III & IV & IV & IV & IV & IV & IV & IV & IV \\
$6 \mathrm{~m}$ & II & II & II & II & III & III & III & III & IV & IV & IV & IV & IV & IV & IV \\
$10 \mathrm{~m}$ & II & II & II & II & III & III & III & III & III & IV & IV & IV & IV & IV & IV \\
$15 \mathrm{~m}$ & II & II & II & II & III & III & III & III & III & IV & IV & IV & IV & IV & IV \\
$20 \mathrm{~m}$ & II & II & II & II & III & III & III & III & III & III & III & III & III & III & III \\
$25 \mathrm{~m}$ & II & II & II & II & II & II & II & II & II & II & II & II & II & II & II \\
\hline
\end{tabular}
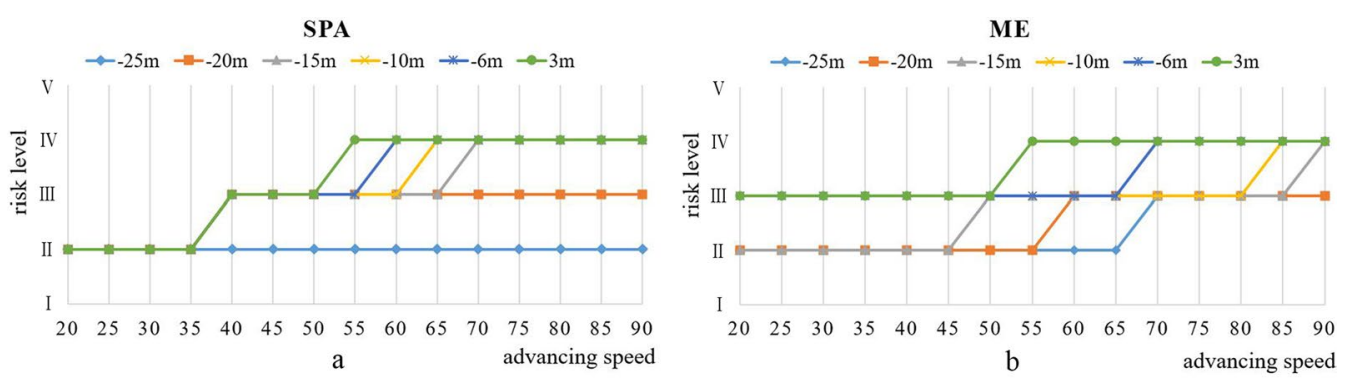

Fig.4 Evaluation results of different methods: a SPA; $\mathbf{b}$ ME

simple and easy to operate using computer programs, making it more efficient than the other methods, and can be used to conduct the evaluation of buildings one by one. For buildings with higher risk level, numerical simulation is used to calculate the specific stress concentration area, and targeted protective measures can be implemented.

(3) A calculation example herein shows that the evaluation results are in line with actual physical results. By using the dynamic changes to the risk levels of heritage buildings in the process of metro shield tunneling, this method can be used to control risk by slowing the advancing speed of the shield machine as appropriate, thereby provide guidance to the construction plan. The SPA method can effectively guide similar projects and is worth popularizing.

It is worth noting that AHP calculated the subjective indexes and weights based upon the experts' knowledge and rich experience. Further studies are required to conduct quantitative analysis objectively. Moreover, the sensitivity analysis of the factors of influence and the scientific selection of safety control measures need to be undertaken in future research, to establish 


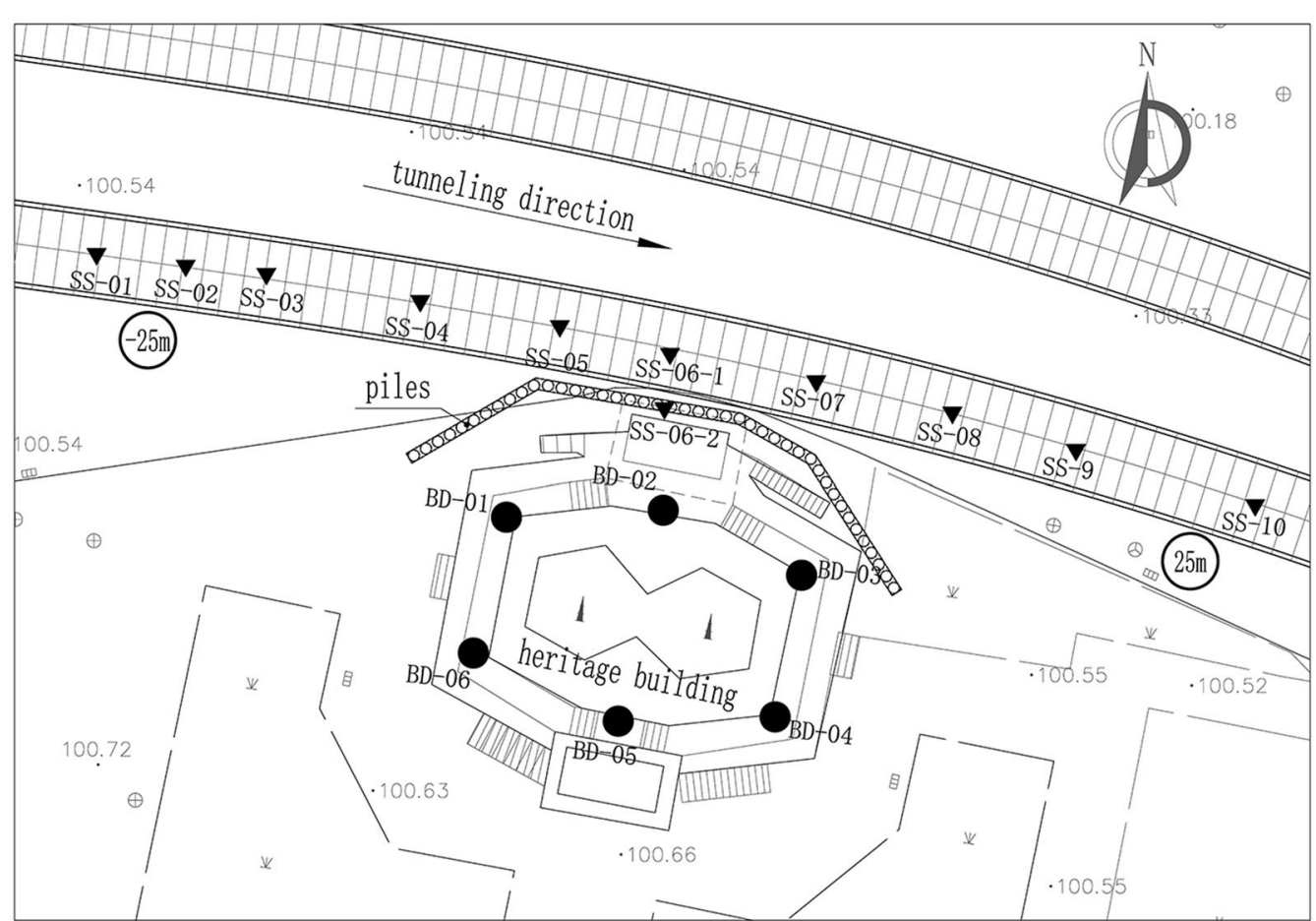

Fig.5 Layout of the monitoring points
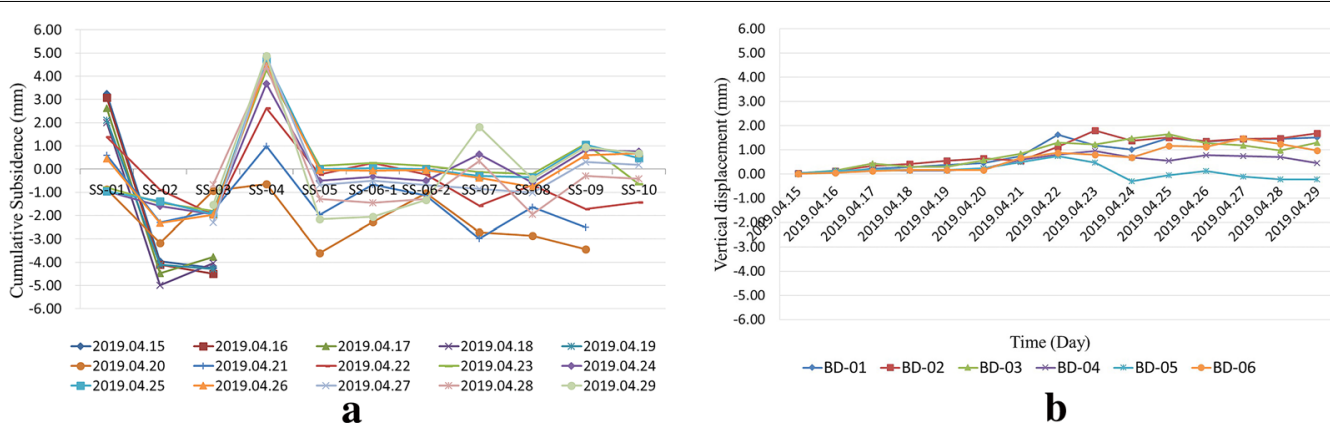

Fig.6 Monitoring data curve: a surface subsidence; $\mathbf{b}$ building displacement 


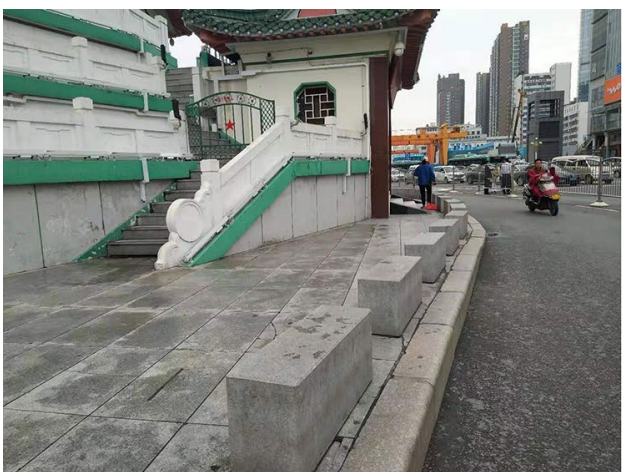

a

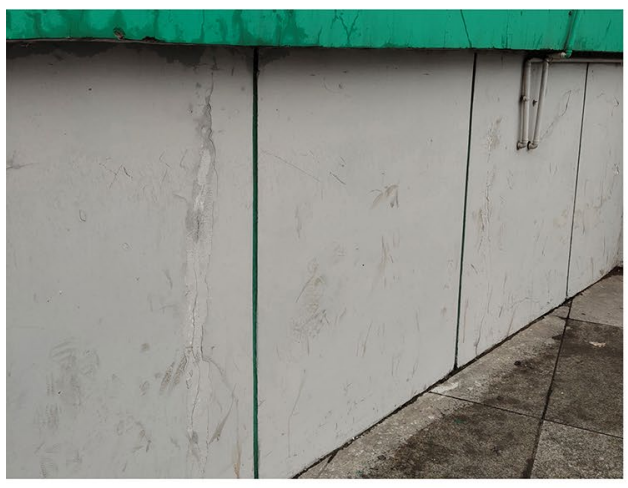

c

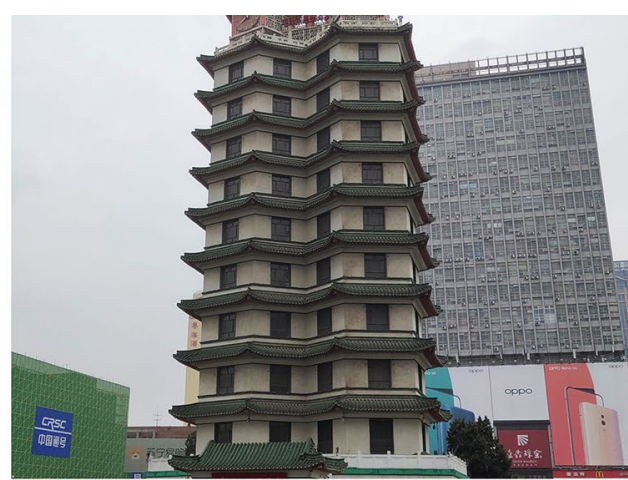

b

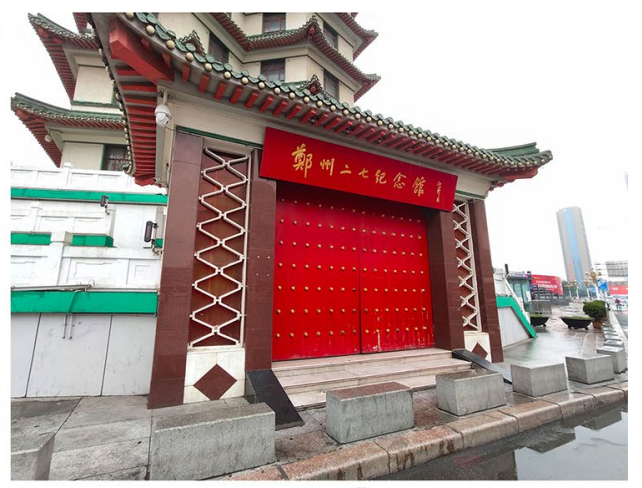

d

Fig.7 Damage to different parts: a outdoor floor; $\mathbf{b}$ main structure; $\mathbf{c}$ non-structural components; $\mathbf{d}$ door

a thorough safety risk management system for heritage buildings.

\section{Abbreviations}

SPA: Set pair analysis; ME: Matter-element; EA: Empirical analysis; FEA: Finite element analysis; MTA: Mathematical theoretical analysis; BNs: Bayesian networks; IF: Information fusion; ECM: Extended cloud model; CMAM: Chromatography multiply assessment method; AHP: Analytic hierarchy process; CWM: Clustering weight method; ZMLT: Zhengzhou Metro Line Three.

\section{Acknowledgements}

The authors highly appreciate the contribution of data collection from China Construction Second Engineering Bureau Co. Ltd.

\section{Authors' contributions}

QW has written the article; CY and LT have reviewed the whole text and have made comments and suggestions to improve it; JA provided the parameters of project; $J$ processed the field data; FW made corrections to improve the paper. All authors read and approved the final manuscript.

\section{Funding}

This study was financially supported by the National Natural Science Foundation of China (Grant Nos. 51478007, 51978005).

\section{Availability of data and materials}

All data generated or analyzed during this study are included in this published article.

\section{Competing interests}

The authors declare that they have no competing interests.

\section{Author details}

${ }_{1}^{1}$ Beijing Historical Building Protection Engineering Technology Research Center, Beijing University of Technology, Beijing 100124, China. ${ }^{2}$ Institute of Architecture and Public Art, Chinese National Academy of Arts, Beijing 100029, China. ${ }^{3}$ China Construction Second Engineering Bureau Co. Ltd, Beijing 100160, China. ${ }^{4}$ Institute of Urban Design, Beijing University of Technology, Beijing 100124, China.

Received: 14 May 2020 Accepted: 18 September 2020

Published online: 12 October 2020

\section{References}

1. Song Y, LV C. An empirical study of evaluation of urban rail transit operation efficiency in China. In: Proceedings of the 2013 International conference on electrical and information technologies for rail transportation. Berlin: Springer; 2014. 
2. Li X, Yang T, Shi Q. Applicative suburban line pattern of urban rail transit in China. In: 13th COTA international conference of transportation professionals (CICTP), Shenzhen, PRC; 2013.

3. Zhang L, Wu X, Liu W, Skibniewski MJ. Optimal strategy to mitigate tunnel-induced settlement in soft soils:simulation approach. J Perform Constr Fac. 2019;33:1-14.

4. Zhang L, Wu X, Zhu H, AbouRizk SM. Perceiving safety risk of buildings adjacent to tunneling excavation: an information fusion approach. Automat Constr. 2017:73:88-101.

5. Rampello S, Callisto L, Soccodato F, Viggiani G. Evaluating the effects of tunnelling on historical buildings: the example of a new subway in Rome. In: 7th international symposium on geotechnical aspects of underground construction in soft ground, Rome, Italy. 2012.

6. Chang $\mathrm{H}$. Heritage Impact Assessment Study of the Xi'an Urban Rail Transit Planning. Doctoral Thesis, Xi'an University of Architecture and Technology, Xi'an; 2013.

7. Haji TK, Marshall AM, Franza A. Mixed empirical-numerical method for investigating tunnelling effects on structures. Tunn Undergr Sp Tech. 2018;73:92-104

8. Osborne D. Alas, alas. House, oh house!': the collapse of the Cologne City Archive. J Urban Cult Studies. 2014;1:395-416.

9. Bilotta E, Russo G. Ground movements induced by tunnel boring in Naples. In: 2012 Proceedings of the 7th international symposium on geotechnical aspects of underground construction in soft ground, London. 2012

10. Franco VH, Gitirana GDFN, de Assis AP. Probabilistic assessment of tunneling-induced building damage. Comput Geotech. 2019:113:103097.

11. Sirivachiraporn A, Phienwej N. Ground movements in EPB shield tunneling of Bangkok subway project and impacts on adjacent buildings. Tunnelling Undergr Space Technol Incorp Trenchless Technol Res. 2012;30:10-24.

12. Camós C, Molins C. 3D analytical prediction of building damage due to ground subsidence produced by tunneling. Tunn Undergr Sp Tech. 2015;50:424-37.

13. Wu X, Jiang Z, Zhang L, Skibniewski MJ, Zhong J. Dynamic risk analysis for adjacent buildings in tunneling environments: a Bayesian network based approach. Stoch Env Res Risk a. 2015;29:1447-61.

14. Zhang L, Ding L, Wu X, Skibniewski MJ. An improved Dempster-Shafer approach to construction safety risk perception. Knowl-Based Syst. 2017;132:30-46.

15. Zhang L, Wu X, Ding L, Skibniewski MJ. A novel model for risk assessment of adjacent buildings in tunneling environments. Build Environ. 2013;65:185-94

16. Clarke JA, Laefer DF. Evaluation of risk assessment procedures for buildings adjacent to tunnelling works. Tunn Undergr Sp Tech. 2014;40:333-42.

17. Peck R. Deep excavations and tunneling in soft ground. State of the Art Report. In: Proceeding of 7th international conference on soil mechanics and foundation engineering, Mexico. 1969.

18. Attewell PB, Farmer IW, Glossop NH. Ground deformation caused by tunnelling in a silty alluvial clay. Ground Eng. 1978;11:32-41.

19. Rankin WJ. Ground movements resulting from urban tunnelling: predic tions and effects. Geol Soc Lond Eng Geol Special Publ. 1988;5:79-92.

20. Li X, Zhou W. Analysis on the influence factors' sensitivity of the ground settlement induced by tunnel construction. In: Proceeding of 2 nd national geotechnical and engineering academic congress, Wuhan. 2006.

21. Bilotta E, Paolillo A, Russo G, Aversa S. Displacements induced by tunnelling under a historical building. Tunn Undergr Sp Tech. 2017;61:221-32.

22. Massinas S, Prountzopoulos GK, Bhardwaj V, Saxena A, Clark J, Sakellariou MG. Design aspects of under-passing a city's heritage landmark with epb machines under low overburden; the case of chandpole gate in jaipur metro. India Geotech Geol Eng. 2018;36:3683-705.

23. Zhao K. Set Pair Analysis and its preliminary application. 1st ed. Hangzhou: Zhejiang Science and Technology Press; 2000.

24. Zhao K, Xuan A. Set pair theory-a new theory method of non-define and its applications. Systems Eng. 1996;14:18-23.

25. Kutut $\mathrm{V}$, Zavadskas EK, Lazauskas M. Assessment of priority alternatives for preservation of historic buildings using model based on ARAS and AHP methods. Arch Civ Mech Eng. 2014;14:287-94.

26. Di Angelo L, Di Stefano P, Fratocchi L, Marzola A. An AHP-based method for choosing the best 3D scanner for cultural heritage applications. J Cult Herit. 2018:34:109-15.
27. Li S, Li JZ. Hybridising human judgment, AHP, simulation and a fuzzy expert system for strategy formulation under uncertainty. Expert Syst Appl. 2009;36:5557-64.

28. Gao Z, Ma D, Wang W, Guo X, Ge Q. Development and application of ancient timber buildings structural condition assessment model based on a fuzzy matter-element model that includes asymmetric proximity. Math Probl Eng. 2018;2018:1-12.

29. Qiao L, Zhang Y, Ma W, Yang X, Li J. Analysis model for forecasting extreme temperature using refined rank set pair. Therm Sci. 2013;17:1369-74

30. Ministry of Housing and Urban-Rural Development of the People's Republic of China. GB 50292-2015-Standard for appraisal of reliability of civil buildings. Beijing: China Architecture\& Building Press; 2015.

31. Massinas S. Designing a Tunnel. In: Sakellariou M., editors. Tunnel Engineering. 2020. https://doi.org/10.5772/intechopen.90182

32. Ding L, Wu X, Zhang L, Skibniewski MJ. How to protect historical buildings against tunnel-induced damage: a case study in China. J Cult Herit. 2015:16:904-11.

33. Chung H, Lee I, Jung J, Park J. Bayesian networks-based shield TBM risk management system: methodology development and application. Ksce J Civ Eng. 2019;23:452-65.

34. Rudokas K, Landauskas M, Gražulevičiūtè-Vilneiškè I, Viliūnienè O. Valuing the socio-economic benefits of built heritage: local context and mathematical modeling. J Cult Herit. 2019;39:229-37.

35. Wu F. Deformation controlling indices of buildings and structures. Rock Soil Mech. 2010;31:308-16.

36. Zhang L, Wu X, Skibniewski MJ, Fang W, Deng Q. Conservation of historical buildings in tunneling environments: case study of Wuhan metro construction in China. Constr Build Mater. 2015;82:310-22.

37. National Railway Administration of China. TB 10003-2016-Code for design of railway tunnel. Beijing: China Railway Press; 2017.

38. Bai T, Liu S, Liao S. Experimental study of disturbance caused by the advancing speed of shield tunneling in soft soil. Rock Soil Mech. 2016;37:2040-6.

39. Chang S, Zhang S, Xiang B. Geological Engineering Handbook. 5th ed. Beijing: China Architecture \& Building Press; 2018.

40. Zhang Y, Liu S, Wu J, Chen J, Xiao X. Sensitivity and its impact of strata parameters on ground surface settlements during shield tunnelling. Modern Tunnelling Technol. 2019;56:127-34.

41. Wei $G$. Selection and distribution of ground loss ratio induced by shield tunnel construction. Chin J Geotech Eng. 2010;32:1354-61.

42. Yihua $M$, Tuo X. Research of $4 M 1 E^{\prime}$ 's effect on engineering quality based on structural equation model. Syst Eng Procedia. 2011;1:213-20.

43. Kioussi A, Karoglou M, Bakolas A, Labropoulos K, Moropoulou A. Documentation protocols to generate risk indicators regarding degradation processes for cultural heritage risk evaluation. Int arch photogrammetry, remote sens spat inf sci. 2013;XL-5-W2:379-84.

44. Ministry of Housing and Urban-Rural Development of the People's Republic of China. GB 50982-2014-Technincal code for monitoring of building and bridge structures. Beijing: China Architecture\& Building Press; 2014

45. Ministry of Housing and Urban-Rural Development of the People's Republic of China. GB 50911-2013-Code for monitoring measurement of urban rail transit engineering. Beijing: China Architecture\& Building Press; 2013.

46. Saaty TL, Vargas LG. Models, methods, concepts \& applications of the analytic hierarchy process, 1st ed. New York: Kluwer Academic Publishers, 2001; pp.6-7. https://doi.org/10.1007/978-1-4615-1665-1

47. Bilotta E, Russo G. Use of a line of piles to prevent damages induced by tunnel excavation. J Geotech Geoenviron. 2011;137:254-62.

\section{Publisher's Note}

Springer Nature remains neutral with regard to jurisdictional claims in published maps and institutional affiliations. 